NBER WORKING PAPER SERIES

\title{
SCHOOL QUALITY, NEIGHBORHOODS AND HOUSING PRICES: THE IMPACTS OF SCHOOL DESEGREGATION
}

\author{
Thomas J. Kane \\ Douglas O. Staiger \\ Stephanie K. Reigg \\ Working Paper 11347 \\ http://www.nber.org/papers/w11347
NATIONAL BUREAU OF ECONOMIC RESEARCH
1050 Massachusetts Avenue \\ Cambridge, MA 02138 \\ May 2005
}

Support for this work came from the Andrew W. Mellon Foundation. Seminar participants at the NBER Summer Institute, American Economic Association, Princeton University and University of California-Santa Barbara provided valuable comments. Gavin Samms helped with merging school boundary information with the housing parcel locations and Jordan Rickles provided data from the 1990 and 2000 census. Jacqueline McNeil at the Charlotte-Mecklenburg School district and Gary Williamson at the North Carolina Department of Public Instruction provided data and graciously answered our many questions. The views expressed herein are those of the author(s) and do not necessarily reflect the views of the National Bureau of Economic Research.

(C2005 by Thomas J. Kane, Douglas O. Staiger, and Stephanie K. Riegg. All rights reserved. Short sections of text, not to exceed two paragraphs, may be quoted without explicit permission provided that full credit, including () notice, is given to the source. 
School Quality, Neighborhoods and Housing Prices: The Impacts of School Desegregation Thomas J. Kane, Douglas O. Staiger, and Stephanie K. Riegg

NBER Working Paper No. 11347

May 2005

JEL No. J0, R0

\begin{abstract}
$\underline{\text { ABSTRACT }}$
We study the relationship between school characteristics and housing prices in Mecklenburg County, North Carolina between 1994 and 2001. During this period, the school district was operating under a court-imposed desegregation order and redrew a number of school boundaries. We use two different sources of variation to disentangle the effect of schools and other neighborhood characteristics: differences in housing prices along assignment zone boundaries and changes in housing prices following the change in school assignments. We find systematic differences in house prices along school boundaries, although the impact of schools is only one-quarter as large as the naive cross-sectional estimates would imply. Moreover, house prices seem to react to changes in school assignments. Part of the impact of school assignments is mediated by subsequent changes in the characteristics of the population living in the school zone.
\end{abstract}

Thomas J. Kane

UCLA

3250 Public Policy Building

Los Angeles, CA 90095

and NBER

tomkane@ucla.edu

Douglas O. Staiger

Department of Economics

Dartmouth College

Hanover, NH 03755

and NBER

douglas.o.staiger@dartmouth.edu

Stephanie K. Riegg

UCLA

Box 951477

Los Angeles, CA 90095-1477

sriegg@ucla.edu 


\section{Introduction}

The quality of local public schools is widely believed to be a key determinant of housing prices. ${ }^{1}$ However, the strength of the consensus is puzzling, given the formidable empirical challenges facing any homeowner or empirical researcher seeking to answer the question carefully. $^{2}$ First, good schools usually come bundled with other neighborhood qualities-- such as proximity to employment, shopping and recreational conveniences and neighborhood peers.

Because the homebuyers who enjoy (and can afford) such amenities tend to congregate together, it is difficult to isolate the effect of schools from the effect of these other traits that accompany good schools. Second, it is difficult to disentangle the valuation of the schools themselves (school facilities, curriculum, teachers and principals) from the valuation of the quality of peers available at the school. Common measures of school quality (such as test scores) typically reflect both the quality of the education being offered and the characteristics of the incoming students. $^{3}$

We study the impact of various school characteristics on housing prices using data from Mecklenburg County, North Carolina from 1994 through 2001. 4 Because of its unique history, Mecklenburg County is the ideal place to study the effect of schools on housing prices. ${ }^{5}$ First, under a court-imposed desegregation plan in place from 1971 through 2001, the district laid out school boundaries so that the typical school drew students from a range of non-contiguous geographic areas. Out of necessity, school boundaries often crossed the informal lines dividing neighborhoods, since those neighborhoods were often segregated along racial lines. Homes located within a few hundred feet of one another were often assigned to very different schools, with very different mean test scores and racial compositions. Like Black (1999), we focus in the

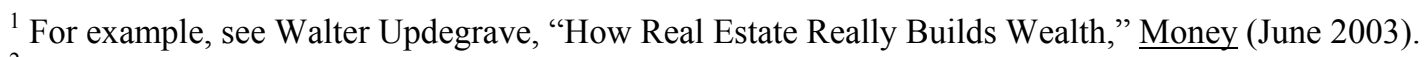

${ }^{2}$ For recent examples, see Black (1999), Bogart and Cromwell (1997), Bogart and Cromwell (2000), Figlio and Lucas (2004), Weimer and Wolkoff (2001) and Kane, Staiger and Samms (2003).

${ }^{3}$ However, as Rothstein (2002) argues, the relative importance of schools and peers in parental preferences would have important implications for the effectiveness of school choice policies in providing incentives for schools to improve.

${ }^{4}$ With a population of 695,000 in 2000 , Mecklenburg County is home of the state's largest city, Charlotte.

${ }^{5}$ In Kane, Staiger and Samms (2003), we used data from Mecklenburg County to study the effects of changes in school test scores and school accountability ratings on housing prices.
} 
first part of the paper on housing prices near school assignment boundaries to identify the effect of schools from the effect of other neighborhood characteristics.

Second, because of rapid population growth and demographic change, the district was forced to redraw the boundaries occasionally to accommodate new schools and to maintain racial balance. For example, with the opening of two new high schools in 1997, 30 percent of the residential units in the county were assigned to a different high school than in the previous year. This provides us with the unique opportunity to study the impact of changes in school assignments on housing prices. Even for those housing parcels with stable school assignments, changes in boundaries elsewhere in their school assignment zones occasionally led to large changes in the characteristics of the students assigned to their schools. Such parcels provide evidence regarding the housing market valuation of school peers.

Both sources of variation-- differences in housing prices along school boundaries, changes in school assignments and changes in peers-- suggest that schools have an impact on housing values. However, the effects of school test scores and the racial composition of schools are considerably smaller - one-quarter to one-fifth as large - as one would infer from the crosssectional relationships between school assignments and housing prices.

We first provide some background on the history of school desegregation in Mecklenburg County. We then describe our data and empirical strategy before providing a more detailed description of the results. Our findings suggest that part of the effect of schools on housing values operates through the characteristics of the population living in different neighborhoods. In the final section of the paper, we present some evidence that the school desegregation plan had an effect on the population living in different parts of the county. Rather than being exogenously determined, housing market segregation is partially a function of the degree of segregation in assigned schools. 


\section{Background on School Assignment in Charlotte-Mecklenburg}

In a landmark decision in 1971 (Swann v. Charlotte-Mecklenburg Bd. of Ed., 402 U. S. 1 (1971)), the U.S. Supreme Court required the Charlotte-Mecklenburg Board of Education to redraw school attendance zones to integrate the district's schools. Earlier court decisions had prevented schools from denying students admission based on race. However, given existing housing market segregation, this still left many neighborhood schools segregated along racial lines. The Swann decision required the Charlotte-Mecklenburg school district to bus students from scattered neighborhoods in order to integrate schools.

Since 1971, the Charlotte-Mecklenburg school board has tried a variety of strategies to ensure racial balancing. For example, over the years, the district has utilized "satellite zones" (bussing students from neighborhoods with a high percentage of one race of students into a neighborhood consisting of another race of students), "mid-pointing" (placing a school at a midpoint between two neighborhoods, while students from the surrounding neighborhood actually attend a different school), "pairing" (having students from two different neighborhoods spend several elementary grades in one neighborhood's school and then spend the remaining grades in the other neighborhood's school) and magnet schools (specialized programs to entice parents to voluntarily send their children to integrated schools).

Figure 1 plots the locations of the housing parcels assigned to four different elementary schools in 1997 (each parcel is identified by the distance in feet from the southern and western edge of the county). In the top left panel, Piney Grove elementary drew students from three geographically distinct neighborhoods in 1997: One neighborhood was 82 percent African American, another was 3 percent African American. The school (identified by the circle symbol) was actually located in a third neighborhood that was 32 percent African American. Sharon Elementary in the bottom left panel was located on the northern edge of an affluent neighborhood that was 1 percent African American and had a median household income of $\$ 122,398$. The school also drew students from a non-contiguous neighborhood to the northwest of the school that was 96 percent African American and had a median household income of 
$\$ 23,506$.

Figure 2 identifies the school assignments of the Greenville/Lincoln neighborhood for the fall of 1997. Residents of the neighborhood were bussed to four different elementary schools, all of which were outside of the neighborhood: Allenbrook Elementary, Nathaniel Alexander Elementary, Piney Grove Elementary and Winding Springs Elementary. Although the Greenville/Lincoln neighborhood is predominantly low-income and African American, residents of the neighborhood were assigned to four very different schools outside of their own neighborhood. The percentage of students in the four schools achieving proficiency on the state test in 1997 ranged from a low of 42 percent at Allenbrook Elementary (to the west of Greenville/Lincoln), to a high of 66 percent at Piney Grove Elementary. As noted in Figure 1, the Piney Grove Elementary school zone includes a higher income, predominantly white neighborhood to the southeast.

In Mecklenburg County, desegregation has proven to be an elusive target. Rapid population growth, demographic change and the flight of many white students from public to private schools, led to the gradual "re-segregation" of previously desegregated schools. A court order in 1980 required the district to make reasonable efforts to keep each school's percentage African American enrollment within 15 percentage points of the district-wide average. (Swann v. Charlotte-Mecklenburg Board of Education, No. 1974 (W.D.N.C. Apr. 17, 1980))

Given rapid population growth and the tendency for the population to sort itself along racial lines, such targets presented a difficult logistical challenge for the district's planning department. The population of Mecklenburg County grew by 36 percent between 1980 and 1990 and by an additional 26 percent between 1990 and 2000. ${ }^{6}$ Meanwhile, the percentage of students in the Charlotte-Mecklenburg Schools who were African American grew from 29 percent in 1971, to 40 percent in 1980 to 45 percent by 2000. As a result, at irregular intervals, the district occasionally redrew school boundaries-particularly when new schools were opened - to maintain schools' percentage of African American students within 15 percentage

\footnotetext{
${ }^{6}$ U.S. Bureau of the Census, County and City Data Book 2000.
} 
points of the district average. (Despite their efforts, a handful of schools in outlying areas remained outside the 15 percentage point bands.)

Figure 3 plots the percentage of residential units in the county affected by the shifting of school boundaries between 1994 and 2002. In 1997, with the opening of several new high schools, 30 percent of the residential units in the county were assigned to a different high school than in the previous year. In 1998, 16 and 18 percent of the residential units were assigned to different elementary and middle schools respectively. In 2001, there was another reshuffling of high school boundaries, with about 12 percent of residential units affected.

In 1997, a white parent sued the school district to challenge the district's policy of creating separate lotteries for black and white students applying for admission at desirable magnet schools. The case led U.S. District Judge Robert Potter to re-open the Swann case to determine if the vestiges of racial discrimination had been eliminated after 30 years of bussing. On September 21, 2001, the Fourth Circuit Court of Appeals ordered the district to dismantle the race-based student assignment plan by the beginning of the 2002-03 school year. ${ }^{7}$ In December of 2001, the district launched a new plan, assigning each parcel to a new home school not based on race, and allowing for public school choice. ${ }^{8}$ (This fact is reflected in Figure 3, as a large share of school assignments shifted again in 2002.)

\section{The Charlotte-Mecklenburg Housing and Test Score Data}

We obtained data on real estate parcels and sales from the Property Assessment and Land Record Management division of Mecklenburg County, North Carolina (population 640,000). There are a total of roughly 330,000 real estate parcels in the county. Of these, approximately two-thirds were single-family homes (including some vacant lots zoned for single family use). We limited the sample to sales of existing homes between January $1^{\text {st }}, 1994$ and December $31^{\text {st }}$, 2001 , and trimmed the data at the $1^{\text {st }}$ and $99^{\text {th }}$ percentiles of the price distribution (approximately

\footnotetext{
${ }^{7}$ A last-minute appeal to the U.S. Supreme Court failed in April 2002, when the justices declined to hear the case. ${ }^{8}$ In a subsequent paper, we will be studying the effect of the end of court-ordered bussing in Charlotte on housing prices.
} 
$\$ 21,909$ and $\$ 749,500$ in 2002 dollars). ${ }^{9} \quad$ After imposing these sample restrictions, we were left with a sample of 89,793 sales for 69,361 parcels.

For each parcel, we have detailed physical information about the property including its exact location (to the foot) and characteristics such as bedrooms, bathrooms, acreage, etc. In addition, the tax assessor's office has identified 1048 different neighborhoods within Mecklenburg County. The typical neighborhood is quite small: half of all parcels are within 400 yards of the center of the neighborhood and ninety-five percent of parcels are within 2000 yards of the center of their neighborhood. Moreover, since these neighborhoods are used for assessment purposes, they were intended to define fairly homogeneous neighborhoods in terms of likely property values for similar structures. We also have the assessor's evaluation of the building quality on each parcel, ranking the quality of building construction in 36 distinct categories. Finally, based on the location of each parcel, we merged on data on median income and percent African American in the census block group. (There were 398 distinct census block groups in the county in 1990 and 373 in 2000.)

\section{School Assignments}

The Charlotte-Mecklenburg School District (CMS) provided us with detailed school boundary information for the period 1993 through the fall of 2001, along with the exact location of every school (elementary, middle and high schools). Changes in school assignments were generally announced in December or January. As a result, we categorize parcels by their school assignments as of January.

Combining the school location and boundary information with the exact location of each parcel (from the housing data), we calculated the straight-line distance of each parcel to its assigned school and to the nearest school assignment boundary (or more precisely, to the closest

\footnotetext{
${ }^{9}$ Since less than one percent of the sample had five sales during our sample period, very few transactions were truncated and we have sales price data for virtually all single family sales transactions occurring between 1994 and 2003.
} 
parcel with a different school assignment). We used all parcels within each school's assignment area to calculate school-level variables that capture the likely socioeconomic status of students at the school: the average percent black and the average median income in the census block group.

\section{School Data}

During our sample period, the Charlotte-Mecklenburg school system had 86 elementary schools, 26 middle schools, and 14 high schools (excluding magnet programs). For each school, we have annual data on student test scores and student demographics.

For 1993 through1999, we have student-level micro-data on math and reading performance and race in grades 3 through 5 for all schools in North Carolina (we do not have the micro-data for 2000-2002.) Using these micro-data, we standardized math and reading scores by grade for all of the elementary schools in Charlotte-Mecklenburg. Using test scores to generate measures of school quality, we estimated school level fixed effects, $*_{\mathrm{s}}$ and ${ }_{\mathrm{s}}$, , using the following specifications:

$$
\begin{aligned}
& \text { Test }_{i t}=\gamma_{o}+\chi_{t}+\delta_{s}+\varepsilon_{i t} \\
& \text { Test }_{i t}=\beta_{o}+\beta_{1} \text { Math }_{i t-1}+\beta_{2} \operatorname{Re} a d_{i t-1}+\beta_{3} \text { Race }_{i}+\beta_{3} \text { ParEd }_{i}+\chi_{t}^{\prime}+\delta_{s}^{\prime}+\varepsilon_{i t}
\end{aligned}
$$

The dependent variable, Test ${ }_{i t}$, represents the test score outcome for student $\mathrm{i}$, in school s, in year $\mathrm{t}$. Each of the equations was estimated separately by grade and subject area (reading and math). We then calculated the mean of $*_{\mathrm{s}}$ and $*_{\mathrm{s}}$, across grades in reading and math. The $*_{\mathrm{s}}$ are essentially mean scores adjusted for grade and year (data similar to these are reported in the Charlotte Observer each fall), while the ${ }_{\text {s' }}$ measure each school's mean "value-added", adjusting for baseline scores, race, parental education, grade and year.

In addition, the North Carolina Department of Public Instruction provided us with data on schools' demographics and a performance composite for each year from 1997 through 2001. The performance composite is the proportion of students scoring above the "proficient" level in 
each grade and subject in a school, and was both publicly reported and an integral part of a school accountability system. The performance composite seems to have been measuring the same attribute as the mean scaled score we calculated from the micro-data: The correlation between the annual performance composite and the mean scaled score $\left(*_{s}\right)$ for 1997 through 1999 (the only three years in which we have both series) was .98.

In earlier work (Kane, Staiger and Samms, 2003), we found that property values did not respond to year-to-year fluctuations in these school measures, but did respond to long run averages of these measures. Therefore, we average over all years available (1993-1999, or 19972002 depending on the measure) to construct measures of test scores and demographics in each school.

The school district also operates a number of magnet schools, which in the years prior to the choice plan were the only way for students to attend schools outside their attendance area. The presence of such options may lead us to understate somewhat the housing market value of school quality, to the extent that we focus on the assigned school. However, the most desirable magnet programs were oversubscribed and subject to lotteries.

\section{Empirical Strategy}

In the literature on school quality and housing values, the primary challenge has been to distinguish between the impact of school quality and the influence of other factors- such as neighborhood amenities and public services- which may be correlated with school quality. To address this issue, we take two distinct approaches. First, following Black (1999), we focus on differences in housing values near school boundaries (parcels within 2000 feet of a school boundary). Second, we look at housing values for parcels that were affected by redistricting both parcels that had stable school assignments but where the peers in the school changed, and parcels that were reassigned to new schools. We control for housing characteristics and a detailed set of fixed effects to capture differences across neighborhoods in house values. In addition, we examine whether households appear to be sorting into neighborhoods based on 
school assignments, and the extent to which this may bias the estimates.

\section{Parcels Near Boundaries}

Our analysis of housing values near school boundaries focuses on elementary school boundaries, and limits the sample to parcels within 2000 feet of a boundary (we find similar results using limits of 500 and 1000 feet). We further limit the sample to boundaries that were stable throughout our sample period (1994-2001), in order to focus on properties for which owners were unlikely to be worried about the boundary changing. We run regressions of the following form:

(1) $\ln ($ price $)=\beta_{1}$ Elementary School Characteristic $+\beta_{2}$ Distance to Elementary School $+\beta_{3}$ House characteristics $+\beta_{4}$ Census tract characteristics

+ Geographic fixed effects

+ Fixed effects for year, month, high school, middle school, and municipality

The primary school characteristic we use is the average scaled test score for grades 3-5 over the years 1993-1999. In addition, we report results using other proxies for school quality based on test scores (the value-added measure discussed above, and the performance composite averaged over 1997-2001) and demographics of the area assigned to each school (average income and percent black in census tracts assigned to each school). Distance is the straight-line distance to the assigned school. House characteristics include common features such as bedrooms, bathrooms and acreage. When indicated in the relevant tables, we also include a full set of dummies capturing the assessors rating of the building grade. Census tract characteristics come from the 2000 census, and include median income, percent black, and percent on public assistance.

Fixed effects are included for every unique boundary in order to capture any local neighborhood effects. Thus, the estimates rely on variation in prices within narrow geographic 
areas separated by an elementary school boundary. To the extent that the school boundaries coincide with natural boundaries between areas with different amenities and public services, our estimates would still be conflating the effects of school quality and other characteristics. As a result, rather than simply include boundaries for pairs of schools, we sought other ways to identify differences between neighborhoods. The tax assessor's office has identified 1048 different neighborhoods within Mecklenburg County, and we experiment with including fixed effects for each of these neighborhoods (interacted with boundary), thereby identifying the impact of school quality for properties in the same neighborhood assigned to different schools. The use of the neighborhood dummies also allows us to control for variation in housing prices along major roadways and other natural barriers, to the extent that bordering properties are recognized as being in different neighborhoods. However, to the extent that the tax assessor distinguishes neighborhoods based on differences in prices (which may be the result of differences in school assignment), controlling for neighborhood may bias the results toward boundaries where there is little difference in property values. Therefore, as a final alternative, we formed more exogenous "neighborhood" dummies by dividing the county into 2500 -foot square blocks.

Mecklenburg County includes the city of Charlotte, as well as six additional municipalities (Cornelius, Davidson, Huntersville, Matthews, Mint Hill and Pineville). Tax rates vary by municipality; the quality of city services may also vary. In most cases, the neighborhood definitions lie within municipality boundaries and, therefore, implicitly control for these factors too. However, neighborhood boundaries do cross municipality boundaries. As a result, we include fixed effects for municipalities, implicitly controlling for tax rate differences and other differences between municipalities.

Figure 4 summarizes the geographic dimensions of the data. On the left hand side, we plot the coordinates of all residential parcels with sales between 1994 and 2001 in Mecklenburg County by their distance in feet from the southern and western edges of the county. The right hand figure plots the locations of sales for the subset of parcels that were located within 2000 
feet of the closest school boundary. To highlight the location of the boundaries, the points on either side of each boundary were shaded a different color. Given the smaller lot sizes in the inner city, many of those parcels that were close to boundaries were drawn from the central part of the county. However, it is also apparent from Figure 4 that the effect of school assignments will be evaluated for properties in very close proximity to one another and that there are a large number of boundaries to exploit.

In focusing on school boundaries, we must assume that unobserved factors affecting house prices change "smoothly" across space, and are not systematically correlated with school test scores across the boundaries themselves. Of course, simple models of residential choice suggest that there would be substantial sorting along these stable school boundaries. For example, families who are willing to pay more to live in a school attendance area with better schools may have higher income and may also invest more in their homes. Even if houses and neighborhoods are very similar on either side of a school border when the boundary is originally drawn, the similarity may not last long as properties are bought and sold, as neighbors change, and as houses depreciate and are improved. To the extent this sorting occurs, it will bias boundary estimates toward finding a positive association between school quality and property value, unless one fully controls for these other differences across boundaries.

While we cannot test whether the unobserved factors systematically differ across school boundaries without an instrument, we do investigate whether there is sorting on observable variables at the boundary. We do this in three ways. First, we estimate the relationship between house prices and test scores at the boundary (as in equation 1) using increasingly detailed covariates on the house and neighborhood. If the estimated effect of school quality is smaller with better controls, this suggests that homes assigned to better schools are also better on other dimensions. More directly, we estimate models similar to equation 1 but using house and neighborhood characteristics as the dependent variable (e.g., acreage, number of bedrooms, heated square footage, income in census tract) to see whether these observable measures differ for those properties in areas assigned to higher performing schools. Finally, we conduct an 
explicit discontinuity analysis, looking at whether both house prices and house and neighborhood characteristics change discontinuously at the boundary between low and high performing schools. More specifically, we estimate the price in 400-foot intervals from a regression with the same specification as in equation 1, except rather than including test scores we include dummy variables for 400-foot intervals from a boundary (distinguishing between intervals in the high and low scoring school zone). We limited this analysis to boundaries where there was at least a .25 student-level standard deviation difference in mean test scores between the schools on the high-scoring and low-scoring side of the boundaries.

\section{Parcels Affected by Redistricting}

An alternative approach to comparing parcels with stable school assignments at a point in time is to compare parcels affected by redistricting over time. Redistricting affected parcels in two distinct ways. First, and most obviously, many parcels were assigned to new schools at both the elementary, middle and high school level. But in addition, even parcels that were not reassigned may have been affected by redistricting through peer effects, if the redistricting significantly altered the mix of students attending a school, by changing boundaries elsewhere. Thus, in this analysis, we use proxies for school quality at the elementary, middle and high school level that (where possible) are constructed to capture variation over time in each school.

To analyze the effect of redistricting on housing values, we use the full sample of sales from 1994 to 2001, including both parcels with stable school assignments and parcels that were redistricted. Nearly two-thirds of all parcels were redistricted at either the elementary, middle or high school level during this period. Of those parcels that were redistricted at least once, over half were redistricted exactly once and at only one level (elementary, middle or high), while a third were redistricted at multiple levels (e.g. elementary and middle) and the remainder were redistricted multiple times for at least one level.

For this sample of sales, we run regressions of the form: 
(2) $\ln ($ price $)=\beta_{1}$ School measure $+\beta_{2}$ Distance

$+\beta_{3}$ House characteristics $+\beta_{4}$ Census tract characteristics

+ pre-post school fixed effects

+ Fixed effects for year, month, and municipality

This specification is similar to that used for the boundary analysis with two important differences. First, we include school and distance measures at the elementary, middle and high school level, since redistricting affects school assignment at all three levels. We consider two types of school measures that are closely related. The first type of school measure is based on the average performance composite and percent black in each school. This data is only available between 1998 and 2001 (and only 2001 for percent black), so cannot be used to measure changes over time within a school in our sample. Therefore, for each school we construct a fixed measure that is the average of these variables over all the years available. The two measures are strongly correlated (roughly -0.8 ), so each measure most likely captures a combination of the instructional quality and the socioeconomic status of peers at the school. Since these school measures do not vary within school over time, all of the changes over time for a given parcel will be the result of reassignment. Our second type of school measure is a peer measure, constructed using only information on which parcels were assigned to each school in each year. The first measure was the average percent black in the census tracts of parcels assigned to each school. The second measure was the average median income in census tracts of parcels assigned to each school. Thus, all of the variation in these measures was generated by changes in assignments, rather than actual changes in the student population at the school. We do this for two reasons. First, we do not have consistent data on race or other socio-economic indicators for our schools over our entire sample period. Second, even without redistricting, natural changes in neighborhoods over time will generate both changes in peers and changes in home prices, and this source of variation is not the focus of our analysis.

The second major difference in this specification from the boundary analysis is that we now include fixed effects for each combination of elementary-middle-high school assignments 
observed in our sample. For example, in parcels with exactly one change in assignment, this means we include a fixed effect for every pre-post combination of school assignments. As a result, this analysis ignores any variation across parcels in school assignment, and is identified exclusively using changes in school measures that occur over time. The variation in the school measures over time comes primarily from parcels that were re-assigned to new schools. For the peer measures (percent black and median income in census tracts assigned to the school), there is additional variation over time even for parcels assigned to the same school throughout our sample period.

As in the boundary analysis, we must assume that unobserved factors affecting house prices do not change when school assignments change. The same type of sorting of households that may occur around school boundaries may also occur over time, as families move in and out of a neighborhood that has been assigned to a new school. We examine whether households appear to be sorting into neighborhoods based on school assignments in three ways. First, we ask whether the changes in house values coincide closely in time with the changes in school assignments, or whether there are long lags as might be expected if the effect was occurring because of changes in neighborhood composition. Second, we investigate whether the effects of school assignment can be separately identified from other factors that are trending over time within the neighborhood. Finally, we look directly at how school assignment was related to changes in the socioeconomic composition of census tracts between 1990 and 2000.

\section{Results using Parcels at School Boundaries}

In this section, we report on differences in house prices along elementary school boundaries. The key identifying assumption is that neighborhood characteristics change "smoothly" while school assignments change discontinuously at the boundaries. We find a significant positive relationship between test performance and housing values on the higher performing side of the boundary. However, other housing and neighborhood characteristics also seem to change discontinuously at the boundaries, suggesting that test performance may proxy 
for unmeasured characteristics of the house or its neighborhood.

\section{Results using School Boundaries}

Table 1 presents the coefficients on elementary school test scores (in student-level standard deviation units) and distance to the elementary school (in miles). In columns (1) through (5), we introduce increasingly detailed control variables. The dependent variable is the natural log of sales price. The sample consists of all sales between 1994 and 2001 for parcels within 2000 feet of a stable school boundary, and where the minimum distance between residential parcels on either side of the boundary was less than 500 feet (to avoid boundaries at waterways and major thoroughfares). In the first column, we control for a set of base covariates including dummies for month and year of sale, dummies for the municipality in which the property may be located, dummies for the middle and high school assigned to the property, and house characteristics such as the number of bedrooms and bathrooms (for a full list of covariates, see notes to the table). The second column adds fixed effects for each unique boundary, in order to control for local conditions around each boundary. The third column goes even further, breaking up the area around each boundary into separate neighborhoods (as defined by the tax assessor's office) and including fixed effects for every boundary-neighborhood combination. The fourth column includes controls characteristics of the census tract and thirty-six building grade dummies from the assessor's office.

All of the specifications in Table 1 suggest that mean test scores are significantly related to property values, but the estimated impact shrinks considerably with more detailed controls. With no fixed effects included for boundary or neighborhood (column 1), we estimate a one student-level standard deviation difference in school test scores is associated with a $.527 \log$ point increase in housing values. Controlling for 84 boundary fixed effects cut this estimate nearly in half, to $.311 \log$ points, and further controlling for neighborhoods within each boundary (by including boundary-neighborhood fixed effects) reduced the estimate to .138. Finally the estimated effect of test scores drops to .098 when we further control for the assessors rating of 
the building grade and census tract characteristics (median income, percent black, and percent on public assistance). ${ }^{10}$

By conditioning on neighborhood-by-boundary fixed effects in columns (3) and (4), our intention was to focus on differences in housing prices along school boundaries within physically and socially homogeneous neighborhoods. But the assessor's office may also be drawing boundaries to identify neighborhoods that are homogeneous in price. When a school assignment leads to a difference in mean price within a pre-existing neighborhood, the assessor's office may redraw neighborhood boundaries to reflect that new equilibrium. As an alternative, we arbitrarily overlaid the county with a square grid, identifying geographic areas that were 2500 by 2500 foot squares. Continuing to include only the houses near the school boundaries, we included fixed effects for each 2500 by 2500 foot block area, while continuing to control for the full set of building characteristics and census tract controls. The resulting estimate may reduce the negative bias which would result if neighborhood boundaries are defined endogenously based on price, but it may also raise introduce a positive bias due to physical and social differences between neighborhoods. The resulting estimate is only slightly larger-- .128 log points per standard deviation in school test scores.

\section{Magnitude of Impact Relative to Private School Tuition}

Of course, parents are not required to send their children to the local public schools. They may also choose to send their children to private schools. As a result, private school tuition provides an upper bound on the price families would be willing to pay to live in a high quality school zone. Fourteen percent of the children in grades 1 through 12 in Mecklenburg County attended private schools at the time of the 2000 Census. Tuition at private schools in Mecklenburg County area averaged $\$ 7,300$ (ranging from an average of $\$ 4,900$ at the Christian

\footnotetext{
${ }^{10}$ The impacts of school test scores in columns (3) and (4) are similar to estimates in Black (1999), who found that a school-level standard deviation in elementary school test scores was associated with a 2.2 percentage point difference in housing price after controlling for boundaries. In Charlotte, a school-level standard deviation is equal to .21 student-level standard deviations. Multiplying the coefficients from columns (3) or (4) in Table 1 by .21 implies a percentage point difference of roughly 2 percentage points per one school-level standard deviation.
} 
schools, to $\$ 6,300$ at the Catholic Schools and $\$ 11,368$ at the non-religious private schools). ${ }^{11}$ Assuming that there were a good private school option available at that price, a parent with one child would not be willing to pay more than $\$ 7,300$ per year on the margin for the additional capital costs associated with buying a house in a neighborhood with high quality public schools. With a 30-year mortgage rate of 7 percent and a marginal federal tax rate of 25 percent, the $\$ 7,300$ capital cost would imply an upper limit on family’s willingness to pay for a good school in the Charlotte area would be $\$ 121,000$ in additional mortgage value. In 2002 dollars, the median sales price of a single-family home was $\$ 142,000$. The results in Table 1 imply that families would be required to pay roughly 10 percent more to move from an elementary school at the $25^{\text {th }}$ percentile to an elementary school at the $75^{\text {th }}$ percentile (roughly a whole student-level standard deviation difference in mean school test score). This would imply a difference of only $\$ 14,000$ in housing price. In other words, the estimated housing price differential to live in a high quality school zone in Table 1 is much less than the upper limit implied by private school tuition.

\section{Distance to Assigned Elementary School}

Table 1 also reports the effect of distance to the assigned elementary school on housing price. At the school boundaries, distance to the assigned elementary school is also changing discontinuously. The coefficient on distance in column (2), with boundary fixed effects, implies that an additional mile in distance is associated with a $.032 \log$ point difference in house price. The implied impact of travel time convenience is quite large. In the same specification, a student-level standard deviation in school mean test scores is associated with a .311 log point difference in price. A student-level standard deviation represents the difference in score between the $10^{\text {th }}$ percentile school and the $90^{\text {th }}$ percentile school. So the estimates in column (2) imply that moving from the $10^{\text {th }}$ percentile school to $90^{\text {th }}$ percentile school in the district in terms of

\footnotetext{
${ }^{11}$ These are the enrollment-weighted mean tuition for 88 private schools listed at the www.charlotteparent.com web site.
} 
mean test scores is equivalent to an extra 10 miles in distance. The coefficient is not statistically distinguishable from zero in columns (3) and (4), with boundary by neighborhood fixed effects included. However, in column (5) with 2500 square foot controls, the estimated coefficient implies that moving from the $10^{\text {th }}$ percentile to the $90^{\text {th }}$ percentile in terms of mean school test scores was equivalent to a 14 mile difference in distance. (Although somewhat imprecisely estimated, the coefficient has a p-value of .070.)

\section{Other Measures of School Quality}

Table 2 reports the coefficient on four other measures of school quality, using the same specifications reported in Table 1. (For simplicity, we report only the coefficient on school quality from each of the specifications.) The first row reports the results using the mean percentage of students in each school scoring at the proficient level on the state test over the period 1997 through 2001. In column (3), with boundary-by-neighborhood fixed effects, a ten percentage point difference in proficiency is associated with a 3 percentage point difference in price.

We also calculated the mean characteristics of the population in each school zone, using the characteristics of the population living in those areas in the 2000 census. The mean test score is highly correlated with both the median income in the elementary school zone (corr $=.77$ ) and the percent of the population in the school zone that was African American (corr=-.77). (These means are calculated for the whole school zone and are not estimated only for those block groups near the boundaries.) Given their relationship to school test scores, it should not be surprising that we find quite similar results as when using test scores as the regressor. Housing prices are positively associated with the median income in the school zone and negatively associated with the percent of the population in the school zone that is African American.

As noted earlier, we used micro-data for students in the Charlotte-Mecklenburg school district to estimate an estimate of the mean "value-added" within schools-- adjusting for students baseline scores, their race/ethnicity, their parental education and calendar year (and averaging the 
effects estimated separately by grade and subject area). In the fourth row of Table 2, report the results of similar specification using the "value-added" measure to rate school quality. The coefficient on school-level "value-added" was indistinguishable from zero in all of the specifications. The results imply that while housing prices respond to the characteristics of peers in the various schools, but not to estimated "value-added" by the school. This is consistent with the results in Rothstein (2002), and may reflect the difficulty parents face in distinguishing differences in school quality, beyond observing the characteristics of potential peers. ${ }^{12}$

\section{Sub-samples of Parcels}

Table 3 tests the robustness of the findings, by replicating the results for various subsamples of parcels. Column (1) replicates the result in column (3) of Table 1 (including boundary by neighborhood fixed effects), where the sample was limited to parcels within 2000 feet of a home on the other side of a boundary. Column (2) limits the sample to parcels within 1000 feet of a home on the other side of a boundary. The results suggest that a one standard deviation difference in mean school test score is associated with a .153 log point difference in home price. Column (3) limits the sample even further, to parcels within 500 feet of a home on the other side of the boundary. (In many cases, this would comprise a single row of housing on either side of the boundary.) Even for such a narrowly defined sample, the coefficient on test scores suggests that a one standard deviation difference in mean test scores is associated with a $.086 \log$ point difference.

The last two columns of Table 3 test for any differences in the housing price differential associated with test scores in predominantly white and black neighborhoods. Column (4) reports the results for parcels within census block groups less than 12 percent African American (roughly the median parcel.) The results suggest a considerably larger impact than for the pooled sample, with a $.366 \log$ point difference in housing price for each one standard deviation

\footnotetext{
${ }^{12}$ Alternatively, the result may be attributable to the relatively low signal-to-noise ratio in such value-added measures reported in Kane and Staiger (2001).
} 
difference in school test scores. The results in column (5) were estimated for census block groups more than 30 percent African American (roughly the $75^{\text {th }}$ percentile). The impacts of school test scores and distance are both indistinguishable from zero.

It seems that home-buyers paid a higher price on the margin for school quality in predominantly white neighborhoods than in predominantly black and integrated neighborhoods. This need not reflect any difference in valuation of school quality by race. Under the district's desegregation plan, African American youth were granted preference in attending the magnet programs in the district. While such programs were often over-subscribed and rationed by lottery for white youth, the odds of admission were typically much higher for African American youth.

\section{Differences in Observable Housing and Neighborhood Characteristics at Boundaries}

By focusing on boundaries, we have assumed that unobserved neighborhood amenities change "smoothly" at school boundaries. While we obviously cannot test whether the unobserved factors systematically differ across school boundaries, we can test whether observed housing (e.g. building grade, number of bedrooms) and neighborhood (e.g. percent black, median household income) characteristics shift discontinuously at the school boundaries.

In Table 4, we use housing and neighborhood characteristics as dependent variables and report the coefficient on each of the various school characteristics. (We converted the categorical building quality measure into an index, using the coefficients from a regression of $\log$ housing price on the 36 building quality categories as the weights.) The sample is limited to parcels within 2000 feet of school boundaries, and the specification includes boundary-byneighborhood fixed effects, year and month dummies, and municipality dummies. In many of the specifications, observable housing characteristics-- such as the number of bathrooms, heated square footage, building quality and air conditioning — were positively associated with mean test scores and median income in the school zone and negatively associated with the percent African American. (The above characteristics were also associated with building age.) Interestingly, the 
value-added measure was unrelated to all of the housing characteristics except census tract median income. Moreover, the characteristics of the population in the census block group also seemed to change discontinuously at the boundary.

These findings are not inconsistent with Black (1999, Table III), who also found differences in observed housing characteristics between homes on the high- versus low-scoring side of school boundaries. However, the magnitude of the differences, and the sensitivity of the estimates to controlling for these differences in observed housing characteristics, is more pronounced in our data. One potential reason for this difference may be our focus on parcels with stable school assignments throughout the sample period. One could argue that school boards are less likely to change school boundaries where housing quality is starkly different on either side of the boundary (because of pressure from homeowners), or that housing quality differences are more likely to arise in areas with stable boundaries (as high income families move in to areas with good schools). In either case, school boundaries in which differences in school test scores are more strongly correlated with differences in housing and neighborhood characteristics would tend to be over-represented in our sample.

In Figures 5 through 8, we investigate the discontinuity in housing prices at school boundaries. If school assignment is the primary factor underlying the increase in property values, then housing prices should rise abruptly at the boundary while other housing and neighborhood factors should not show any sign of discontinuity at the boundary. To test for discontinuities at the boundary, we estimated models identical to those reported in column (2) of Tables 1 and 2 (with boundary fixed effects). But rather than including test scores we included dummy variables for 400 -foot intervals from the boundary. The interval 0-400 feet from the boundary with a better school is the omitted reference category. The intervals were defined so that, for example, a home which is 350 feet from the boundary with a better school is assigned a distance of negative 350, and a home which is 350 feet within the better school's boundary is assigned a distance of positive 350 . We limited the analysis to boundaries where there was at least a .25 student-level standard deviation difference in mean test scores between the schools on 
the high-scoring and low-scoring side of the boundaries. There were roughly 3000 home sales in each interval, except for the two intervals within 400 feet (either side) of the boundary that each had roughly 1000 home sales. ${ }^{13}$

As seen in Figure 5, there is a sharp increase in housing prices at the boundary, with prices being roughly 12 percent higher for houses just inside the high-scoring district. The magnitude of this effect is consistent with our earlier estimates: The average difference in scores between the high-scoring school and the low-scoring school was .32, which multiplied by the coefficient from column (2) of Table 1 (.311) would yield an effect on house prices of 9 percent. Thus, we do observe a discontinuity in house prices of about the expected magnitude at the boundary.

However, other housing and neighborhood characteristics also change discretely at the boundary, as can be seen in Figures 6 and 7. Figure 6 plots estimates of the building quality index in 400-foot intervals from the boundary (controlling for boundary fixed effects and the other controls listed in Table 2), while Figure 7 plots analogous estimates of census tract median income. Both building quality and median income follow patterns that are quite similar to that seen for house prices, with building quality increasing by 10 to 20 percent and median income increasing by about ten thousand dollars on the side of the boundary with better test scores.

Not surprisingly, the magnitude and abruptness of the discontinuity in house price is quite sensitive to controlling for house and neighborhood characteristics that change at the boundary. In Figure 8, we plot the price effects in 400-foot intervals, estimated as in Figure 5 but altering the control variables to be more or less detailed. When we include no controls, the discontinuity at the boundary is of similar magnitude but prices appear to drift steadily upward inside the highscoring school zone (and to a lesser extent inside the low-scoring school zone). Controlling for boundary effects and standard house characteristics eliminates much of this upward drift, and

\footnotetext{
${ }^{13}$ The lower numbers of sales within 400 feet of the boundary is an artifact of the way in which we define distance to the boundary. We actually measure distance to the nearest house that sold in a different school attendance area. So 400 feet is an over estimate of how far these homes are from the boundary.
} 
controlling for boundary-neighborhood effects eliminates the drift even further. When we add the controls for census tract characteristics and building grade, the size of the price discontinuity at the boundary is cut in half and prices are estimated to be fairly stable on each side of the boundary. Thus, while the specification with a full set of controls (corresponding to column 4 of Table 1) yields what appears to be a clean discontinuity at the boundary, one could certainly argue that this is the result of additional unobserved house or neighborhood characteristics that change at the boundary, rather than school quality per se.

Although these results do call into question the practicality of disentangling the effect of school quality from other neighborhood variables, they should not be surprising. Some neighborhood amenities - such as proximity to local shopping or soothing ocean breezes-- do not change discontinuously at school boundaries. However, the property right to good schools does change discontinuously at the boundaries. Families who are willing to pay more to live in a school attendance area with higher test scores may also invest more in their homes. Even if houses are very similar on either side of a school border when the boundary is originally drawn, the similarity may not last long as properties are bought and sold, and as houses depreciate and are improved.

\section{Results Based on Changes in School Assignments}

In Table 5, we report estimates of the relationship between school characteristics and housing prices that are identified solely from variation generated by school re-assignments. Each column reports the coefficients for a different set of school measures used in estimating equation (2) on a sample of all sales between 1994 and 2001. For each specification, we included a separate measure reflecting the elementary, middle and high school to which the parcel was assigned. Each specification also included: all of the controls for house and neighborhood characteristics; distance to elementary, middle, and high school; year, month and municipality dummies; and a full set of fixed effects for every pre-post reassignment permutation of elementary, middle and high school. 
The first column of Table 5 reports estimates from a specification that use the average percent black in the census tracts of parcels assigned to each school (separately for the elementary, middle and high school) as a proxy for the peers attending each school. The percent black at the high school is significantly negatively associated with property values. The coefficient implies that a ten-percentage point increase in the black percentage at the high school (roughly one standard deviation) is associated with 4.2 percent lower property values. The coefficient on percent black at the middle school is a third the size and only marginally significant ( $\mathrm{p}=.08$ ), while the coefficient on percent black at the elementary school is both small and insignificant. Thus, property values declined in parcels that were re-assigned to high schools with more black students.

The remaining columns of Table 5 report similar results using other school measures: the average median income in census tracts of parcels assigned to each school, and the average performance composite in each school. A ten percent increase in median income at the high school is associated with 2.3 percent higher property values, while a ten-point increase in the performance composite at the high school is associated with 1.8 percent higher property values. Coefficients for the elementary and middle school measures are not statistically significant, although the elementary school measure has an unexpected sign and is marginally significant in two specifications.

\section{Using Neighborhood and Parcel Fixed Effects}

Table 6 reports the results using a variety of different fixed effects. The first column replicates the first column of Table 5, using fixed effects for school assignment history. The second column includes fixed effects for the interaction between school assignment history and neighborhood. The third column includes fixed effects for the interaction between school assignment history and 2500' block. By including the interaction with school assignment history, each of these estimates is being identified by within neighborhood changes in the characteristics of students at the assigned schools, but allow for changes in the location of sales 
within school assignment history zones. The results are quite similar, implying that a 10 percentage point increase in the percent black in the high school zone is associated with a 4 percent decline in home price and a similar change in a middle school zone is associated with a 1.4 to 1.7 percentage point change in price.

The last column of Table 6 includes fixed effects for housing parcel, and the coefficient on school characteristics is identified by repeat sales for the same parcels before and after the change in school assignments. The standard errors are considerably larger, but the results continue to suggest that changes in the characteristics of students in the school zone are associated with changes in housing prices. Indeed, the coefficient on the percentage African American in the high school zone is slightly higher (implying a 6 percentage point decline in price for every 10 percentage point increase in percent black in the school zone).

Clotfelter (1975) studied the effect of school segregation in Atlanta, using changes in housing prices and high school segregation between 1960 and 1970. His results were quite similar, finding that a 10 percentage point increase in African American enrollment in the assigned high school was associated with a 4.7 percentage point decline in price.

\section{Changes in School Assignments and Peer Effects}

In Table 7, we split the sample into parcels that never had a change in school assignment and parcels that had at least one change in school assignment during our sample period. In order to estimate the model in the sample that never changed schools, we use the measure based on percent black in the census tracts assigned to the school (results are similar using median income). As a summary, we also report specifications that included a combined average measure across elementary, middle and high schools assignments (weighted by number of grades in each school). The results are as expected, with similar estimates in the full sample and the sample that changed schools, and very imprecise estimates in the sample that never changed schools. While one cannot formally reject that the coefficients are equal in the two samples, it is clear that there is little information coming through "peer effects" on the parcels that did not change school 
assignment.

\section{Evidence of Household Sorting}

Tables 5 through 7 suggest that re-assignment to a high school with higher SES students and higher test scores is associated with a rise in property values. But, as we found in the boundary analysis, some of this association between school characteristics and property values may be the result of high SES households moving in to areas that have been re-assigned to better schools. In other words, some of this association may be due to an evolving neighborhood rather than the school per se.

To the extent that neighborhoods change slowly while school assignments change discontinuously, we would expect the change in school assignment to affect property values immediately if schools per se were being valued, while long lags might be expected if the effect was occurring because of changes in neighborhood composition. In Table 8 we report estimates of the same models estimated in the earlier tables, but adding various lags and leads of the school measure. To simplify the table, we only report results for percent black in the census tracts assigned to the high school. Results using the other measures from Table 4 are quite similar, while additional terms for elementary and middle school were both insignificant and had little effect on the reported high school coefficients.

The results of Table 8 suggest that there are long lags in the effect of schools on property values. The first column reports the coefficient on percent black in the high school when no lags are included, and the estimate is similar to those in Table 5. When we add 1-3 lags in the next three columns, nearly all of the effect of percent black in the high school appears to be spread out over as many as 4 years. When lags are included in the model, the cumulative effect of percent black is given by the sum of the lags. Thus, based on the specification with three lags, a tenpercentage point increase in percent black at the high school is associated with a 0.94 percent decline in property values the first year, a $3.12 \%(.094+.218)$ decline after two years, a $5.11 \%$ $(.094+.218+.199)$ decline after three years, and a total decline of $6.46 \%$ over four years. As a 
specification check (and a check of whether re-assignment was anticipated), we include two leads of the percent black at the high school in the final column. The coefficients on the two leads are both small in magnitude and statistically insignificant.

To illustrate the slow adjustment of property values to school reassignment, we split parcels into three groups according to how they were affected by the 1997 high school reassignment: parcels that had an increase of more than five percentage points in percent African American, parcels that had a decrease of more than five percentage points, and the remaining parcels that had little change in percent black in their high school. In Figure 9, we plot the high school percent black for each of these three groups. (Because we use the census block group population figures in 2000 to calculate the percent black in each high school zone, the change in the graph is identified only by changes in assignments and not by population changes between 1990 and 2000.) It is evident in Figure 9 that the school district used the reassignment of school zones in 1997 to increase the degree of racial integration in the district: high school zones that started out with a high percentage of African American students were allocated a larger share of white neighborhoods, while zones with small percentages of African American students received the largest increases in the proportion of students who were African American.

In Figure 10, we plot the average residual for each of these three groups from a regression of log sales price on all of the control variables (including the fixed effects) included in Table 5. One can see a clear rise in prices for parcels that had a decline in percent black in their high school, and a decline for parcels that saw a rise in percent black. But the effects on price are not immediate, and do not flatten out for 3-4 years. The total magnitude of the price change is about six percent for each group, which is in line with what the regression estimates would have implied for a ten percentage point change in percent black in the high school.

The fact that the effect of high-school assignment on property values appears gradually raises two related concerns about how one should interpret these results. First, these gradual effects could be spurious, simply the result of unobserved factors that were trending over time. 
Such pre-existing trends could even have influenced the redistricting decision, for example if urban areas that were being gentrified were targeted for re-assignment. In the first two columns of Table 9 we compare our original estimates (column 1) to estimates from a model that included separate trends for each school zone (where a school zone is defined as every pre-post reassignment combination of elementary, middle and high school). The coefficients fall slightly when these trends are included, although the first two lags remain large and significant. Moreover, the basic pattern of results is quite robust suggesting that the results are not the result of spurious pre-existing trends in property values.

Alternatively, the gradual effect of high-school assignment on property values may reflect the slow evolution of the neighborhood that results from the new school assignment. The remaining columns of Table 9 provide some indirect evidence in favor of this interpretation. If a better school assignment raises property values through altering the population moving in to the neighborhood, one would expect these effects to spill over onto all properties in the neighborhood, not just those that were reassigned to the better school. Thus, one might expect that the effect of school assignment would be at the neighborhood level, rather than at the parcel level. Columns 3-5 of Table 9 contain specification that include only neighborhood fixed effects (column 3), add variables for the average percent black at the high school of all parcels in the neighborhood, and finally add a full set of neighborhood-by-year fixed effects. In both specifications that control for variation at the neighborhood level, we find little evidence that within-neighborhood differences in high school assignments affected property values. The coefficients on percent black for the high school become individually insignificant, and the cumulative effect over all the lags becomes small (under -.05 in both specifications) and statistically insignificant. In contrast, the cumulative effect of the average percent black of the high school of all parcels in the neighborhood is jointly significant and large (-.683). Thus, the effects of high school assignment appear to spill over to the entire neighborhood. 


\section{School Assignments and Population Changes}

Table 10 looks directly at how school assignment was related to changes in the socioeconomic composition of census tracts between 1990 and 2000. This table reports results from regressions that included one observation for every residential parcel. The dependent variable is the change in the percent black of the population in the parcel's census block group. The right hand side variables are the percent black in the school that the parcel was assigned to in 1991 (the earliest year available in our data), and the change in the percent black in the assigned school (because of redistricting) between 1991 and 2000. If the population segregates itself based on school composition, we would expect that both variables would have positive coefficients: areas initially assigned to black schools would become more black, while areas reassigned to a more black school would also become more black. This is exactly the pattern seen in Table 10. The first three columns include measures based on elementary, middle and high school assignment separately. In each specification, a ten percent increase in the percent black at the school in 1991 is associated with between three and six percent more rapid growth in the percent black in the census block. Similarly, a ten percent increase in the percent black at the assigned school between 1991 and 2000 is associated with a roughly three percent increase in percent black in the census block. When elementary, middle and high school measures are all entered simultaneously (column 4), most of the effect appears to load on to the high school coefficients. The fifth column creates an average percent black across all assigned schools, and the results are similar.

The remainder of Table 10 replicates these specifications but controls for potential mean reversion in percent black in the census block by including a variable that measures the difference between the percent black in the census block in 1990 and the percent black in the assigned school in 1991. This term has a negative coefficient of between -.2 and -.4 , suggesting that the race of a census block tends to mean-revert toward the percent black in the assigned school. This mean reversion may occur for purely statistical reasons, because of the noisiness in the census block measure (primarily because of redefinition of the block between censuses). 
Alternatively, one might expect that the coefficient on the baseline difference between block group and school zone captures real changes in the racial mix, as neighborhoods that differ in racial mix from their assigned school tend to evolve toward the school racial mix over time. In either case, the remaining coefficients remain largely unchanged. On balance, therefore, these estimates suggest that there is significant sorting along racial lines in response to school assignments.

\section{Conclusion}

In the local public finance literature, there is a long tradition of attempting to disentangle the value of school quality from other neighborhood amenities. It is a difficult empirical challenge, given that we would expect unmeasured differences in neighborhood characteristics to be correlated with school quality, as result of sorting. Using Black's (1999) approach of focusing on the values of properties near school boundaries we find that a one student-level standard deviation difference in a school's mean test score was associated with a 10 percentage point difference in house value. Given Mecklenburg County's unique history of school desegregation, we also study housing market reactions to changes in school assignments. Our results suggest that changes in the mean characteristics of the students assigned to one's school also have large impacts on housing prices, although prices react with a several year lag.

However, both sets of results suggest that the population living in school assignment is itself a function of school assignments. Proximity to shopping amenities and pleasant breezes may not change discontinuously at school boundaries, but the property right to schools of varying quality does change at the boundary and such rights may be of different value to different groups of people. Bayer, McMillan and Reuben (2004) make the same point in the context of a general equilibrium model, and find that much of the apparent difference in housing value associated with schools is the result of residential sorting. We also observe discontinuous changes in observable housing and population at school boundaries. Moreover, when neighborhoods are reassigned to different schools, the population living in those neighborhoods 
seems to respond. Thus, the impact of schools on housing values appears to be largely indirect, through the residential sorting that goes hand-in-hand with school boundaries and reassignment. 


\section{$\underline{\text { References: }}$}

Bayer, Patrick, Robert McMillan and Kim Reuben, "Residential Segregation in General Equilibrium” Department of Economics, Yale University Working Paper, March 2004.

Black, Sandra E. "Do Better Schools Matter? Parental Valuation of Elementary Education" Quarterly Journal of Economics (1999) Vol. 114, No. 2, pp. 577-599.

Bogart, William T. and Brian A. Cromwell "How Much is a Good School District Worth?" National Tax Journal (1997) Vol. 50, No. 2, pp. 215-232.

Bogart, William T. and Brian A. Cromwell, "How Much is a Neighborhood School Worth?" Journal of Urban Economics (2000) Vol. 47, No. 2, pp. 280-305.

Clotfelter, Charles "The Effect of School Desegregation and Housing Prices" Review of Economics and Statistics (1975) Vol. 57, pp. 446-451.

Epple, Dennis and Richard Romano, "Neighborhood Schools, Choice and the Distribution of Educational Benefits" in Caroline Hoxby (ed.) The Economics of School Choice (Chicago: University of Chicago Press, 2003).

Figlio, David and Maurice Lucas "What's In a Grade? School Report Cards and House Prices" American Economic Review (June 2004) Vol. 94, No. 3, pp. 591-604.

Kane, Thomas J. and Douglas O. Staiger "Improving School Accountability Measures" National Bureau of Economic Research Working Paper No. 8156, March 2001. (Revised 2002)

Kane, Thomas J. and Douglas O. Staiger "Volatility in School Test Scores: Implications for Test-Based Accountability Systems" Brookings Papers on Education Policy, 2002 (Washington, DC: Brookings Institution, 2002a).

Kane, Thomas J. and Douglas O. Staiger "The Promise and Pitfalls of Using Imprecise School Accountability Measures" Journal of Economic Perspectives (2002c)Volume 16, Number 4, pp. 91-114.

Kane, Thomas J., Douglas O. Staiger and Gavin Samms "School Accountability Ratings and Housing Values" in William Gale and Janet Pack (eds.) Brookings-Wharton Papers on Urban Affairs, 2003 (Washington, DC: Brookings Institution, 2003) pp. 83-137.

Nechyba, Thomas "Introducing School Choice into Multidistrict Public School Systems" in Caroline Hoxby (ed.) The Economics of School Choice (Chicago: University of Chicago Press, 2003).

Rothstein, Jesse "Good Principals or Good Peers: Parental Valuation of School Characteristics, Tiebout Equilibrium, and the Incentive Effects of Competition Among Jurisdictions." Princeton University Department of Economics Working Paper, November 2002. 
Weimer, David L. and Michael J. Wolkoff, "School Performance and Housing Values: Using Non-Contiguous District and Incorporation Boundaries to Identify School Effects" National Tax Journal Vol. 54, No. 2, pp. 231-253. 
Figure 1. School Assignments in Four Elementary Schools in 1997
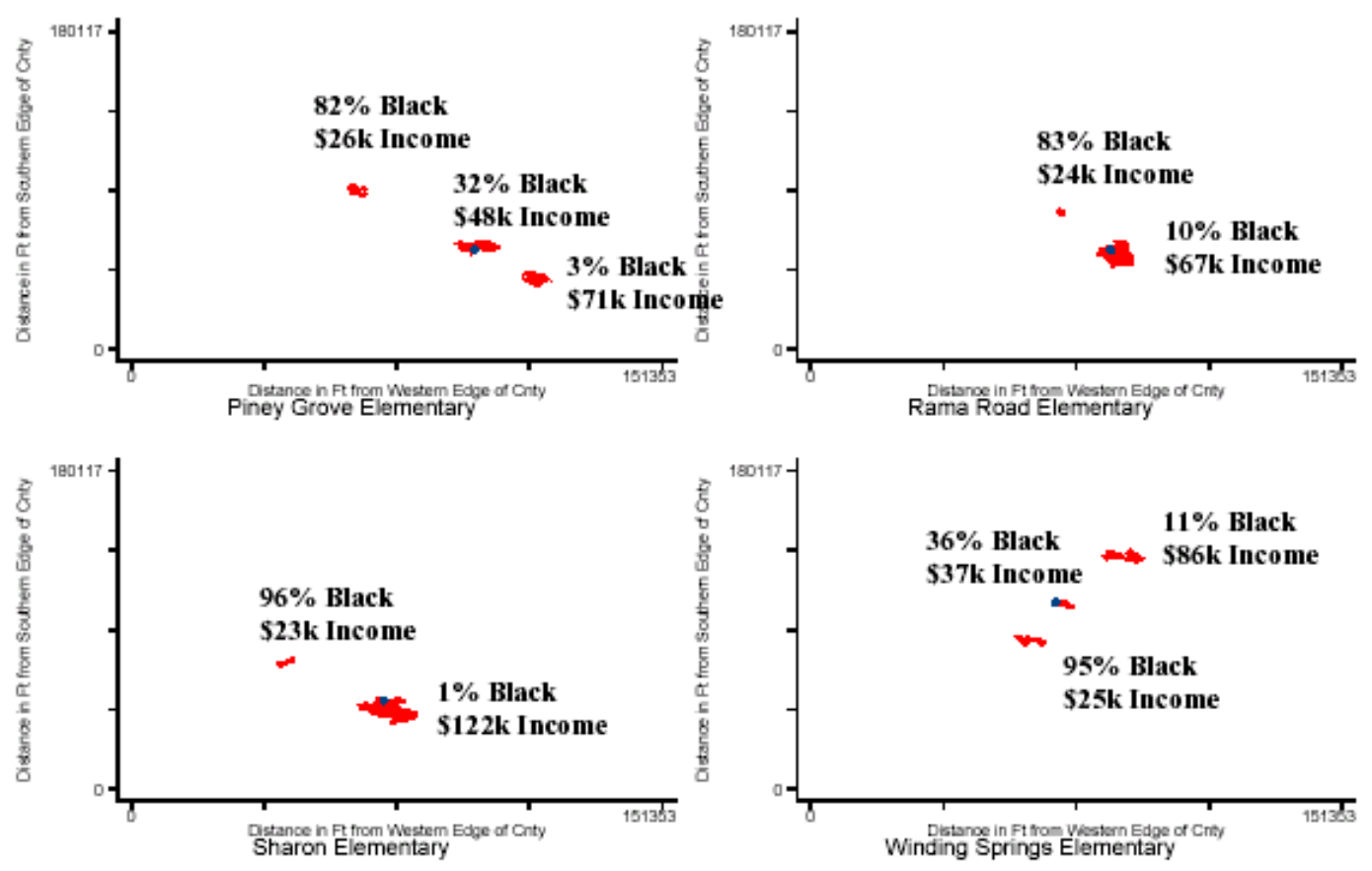
Figure 2. School assignments of the Greenville/Lincoln neighborhood for the fall of 1997.

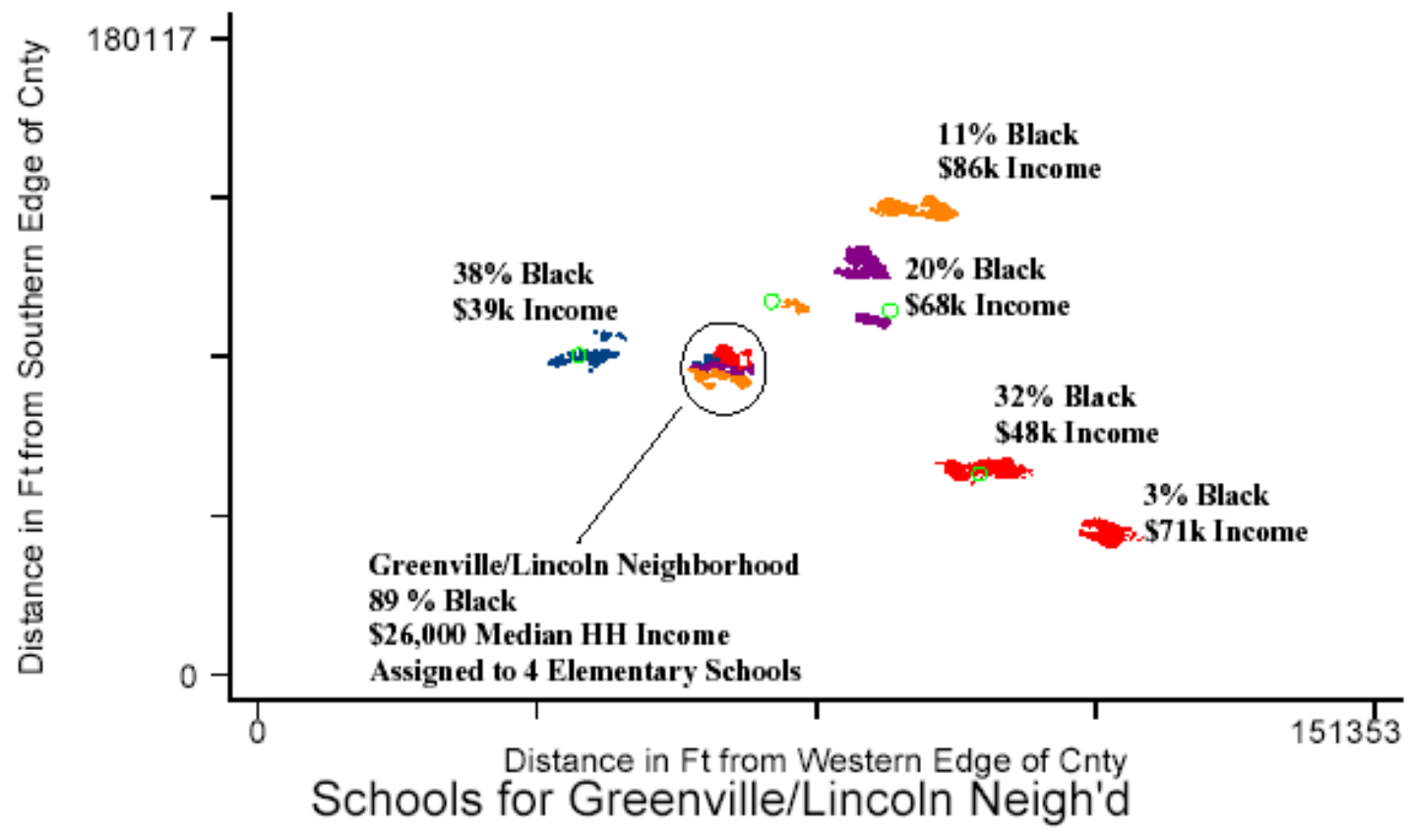


Figure 3. percentage of residential units in the county affected by the shifting of school boundaries between 1994 and 2002.

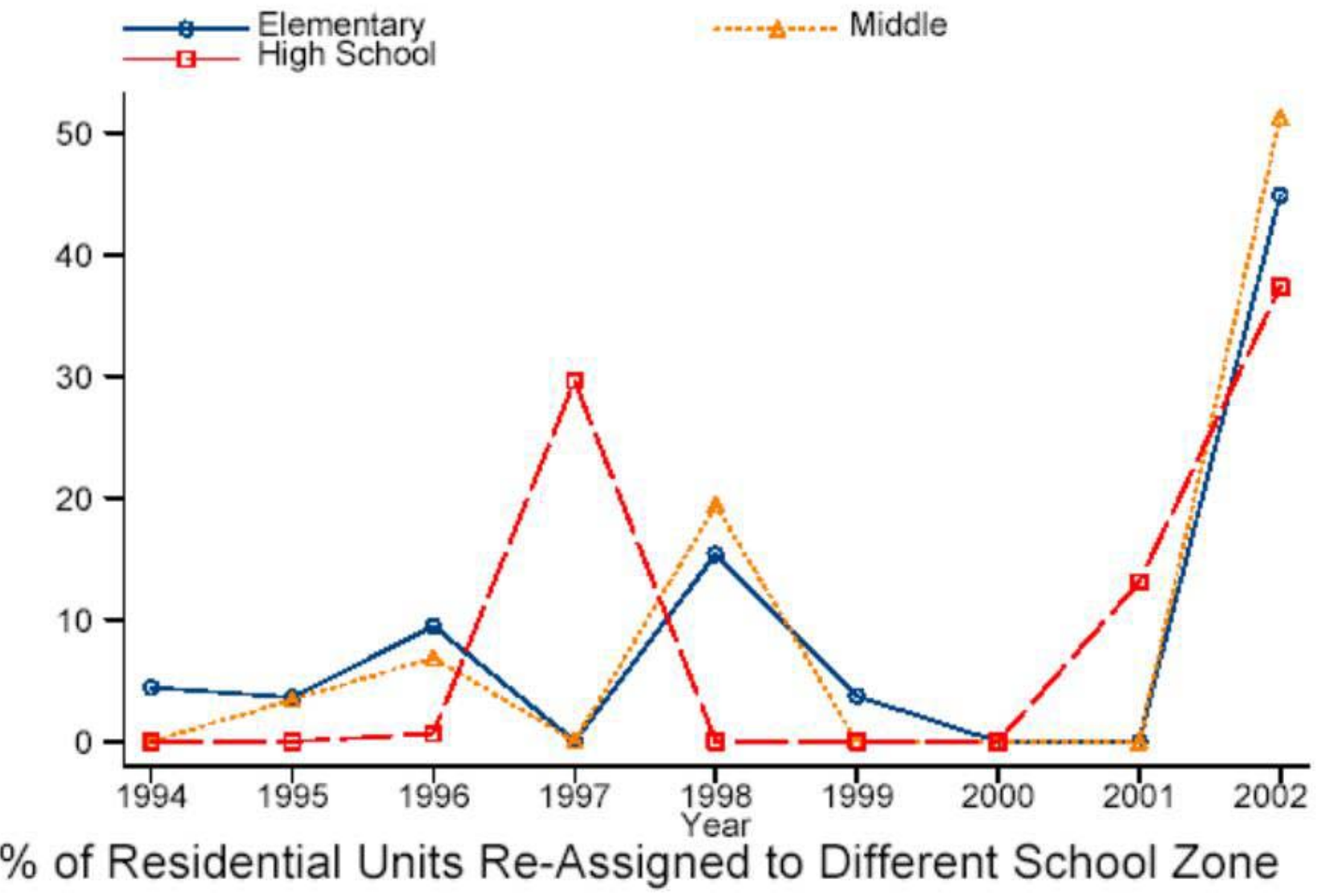


Figure 4. The location of all residential parcels with sales between 1994 and 2001 in Mecklenburg County, and the locations of sales for the subset of parcels located within 2000 feet of the closest school boundary.
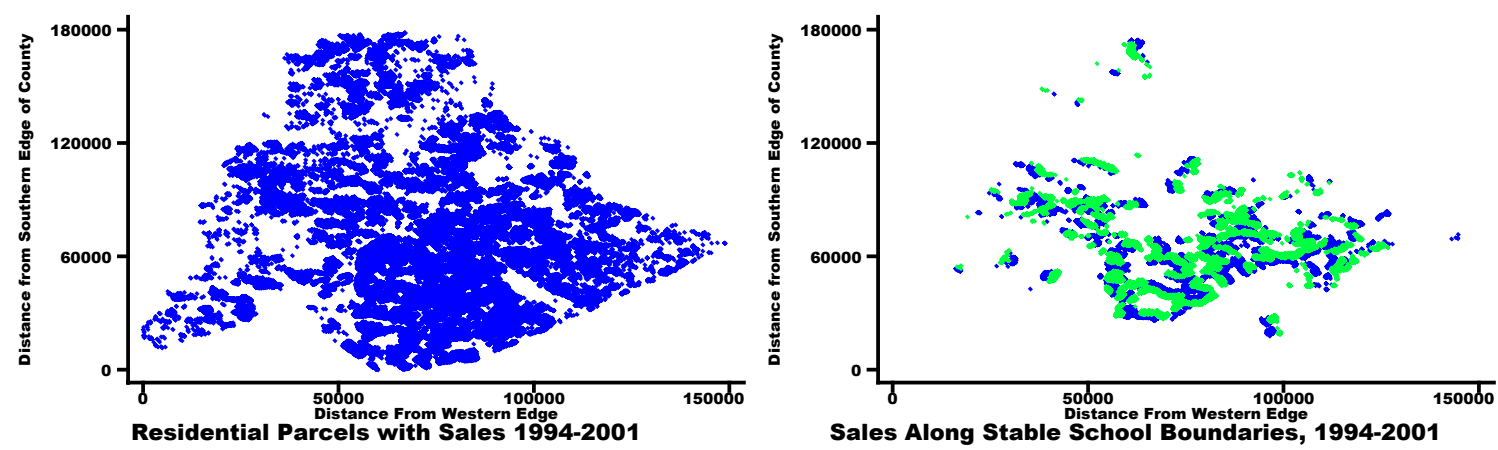
Figure 5. The discontinuity in housing prices at school boundaries.

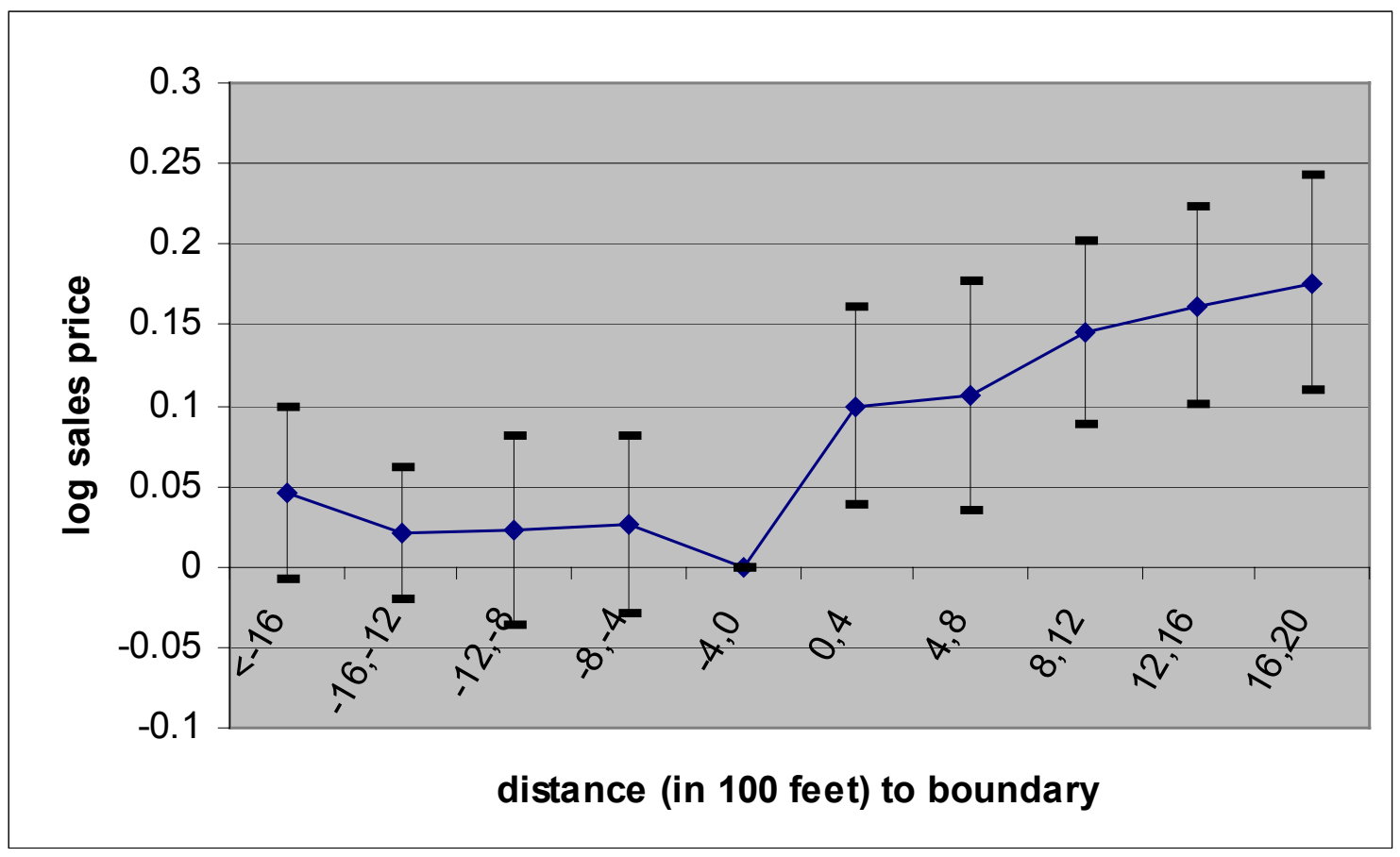


Figure 6. The discontinuity in building quality index at school boundaries.

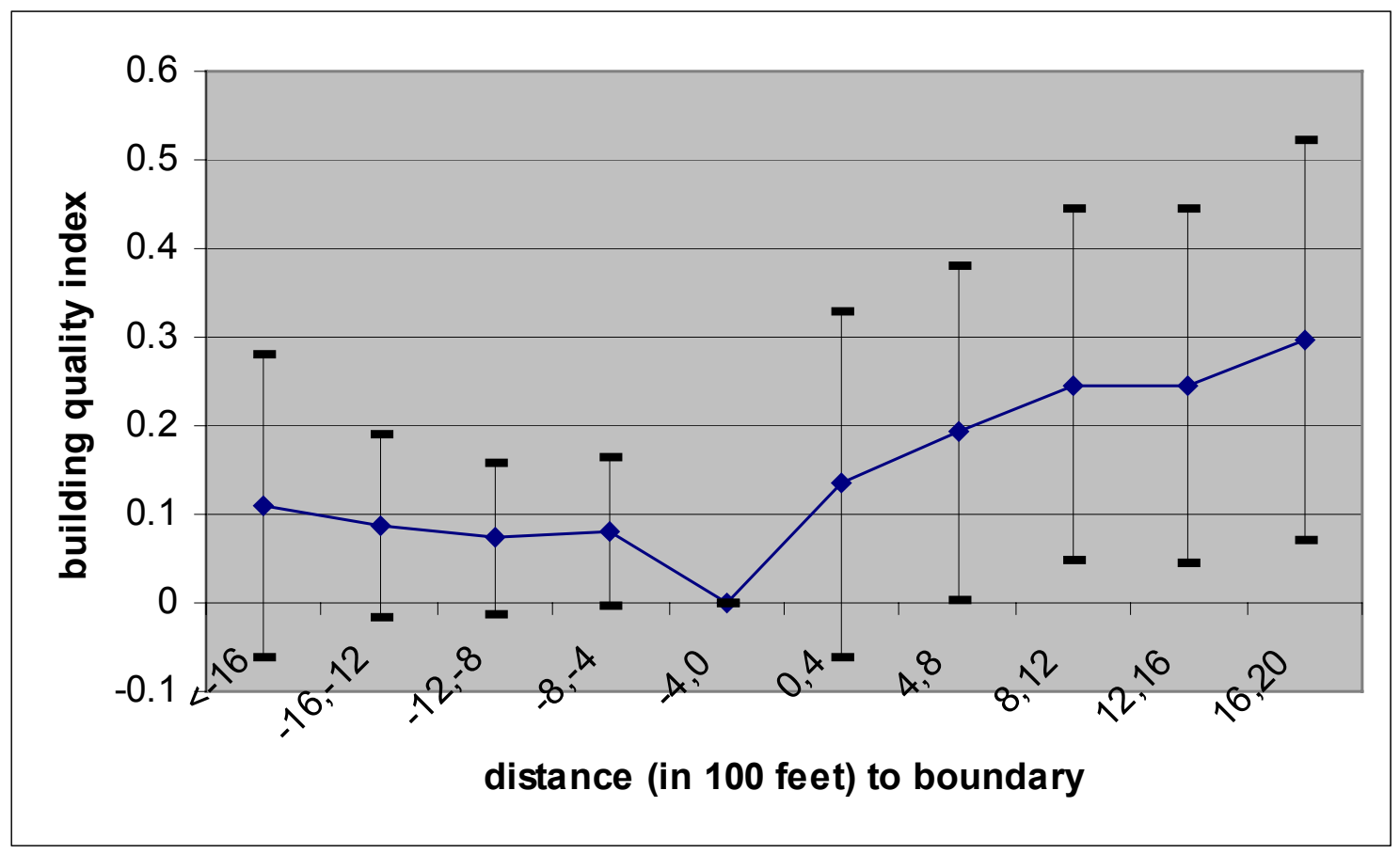


Figure 7. The discontinuity in median census tract income at school boundaries.

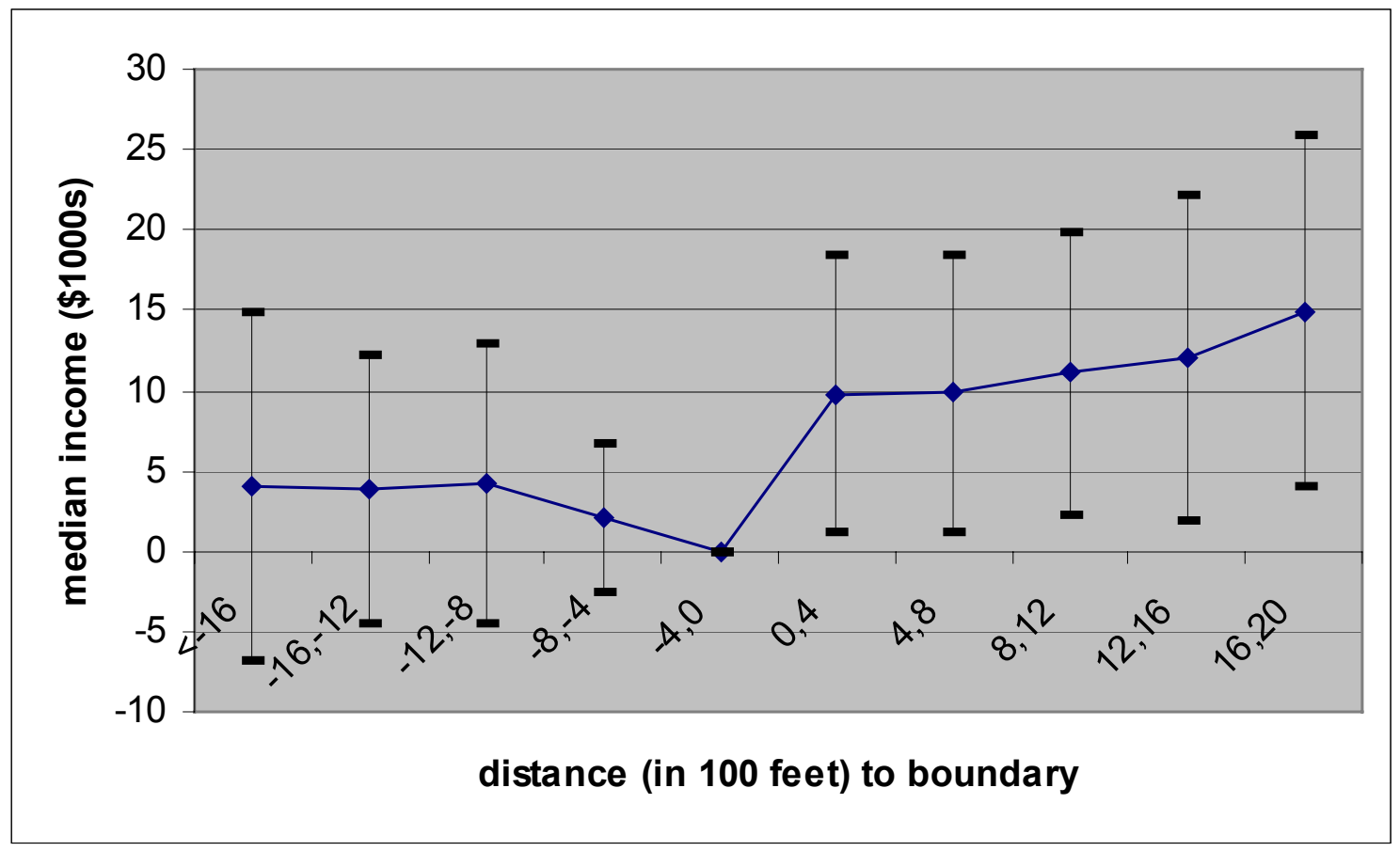


Figure 8. Comparing the discontinuity in housing prices at school boundaries using more or less detailed control variables.

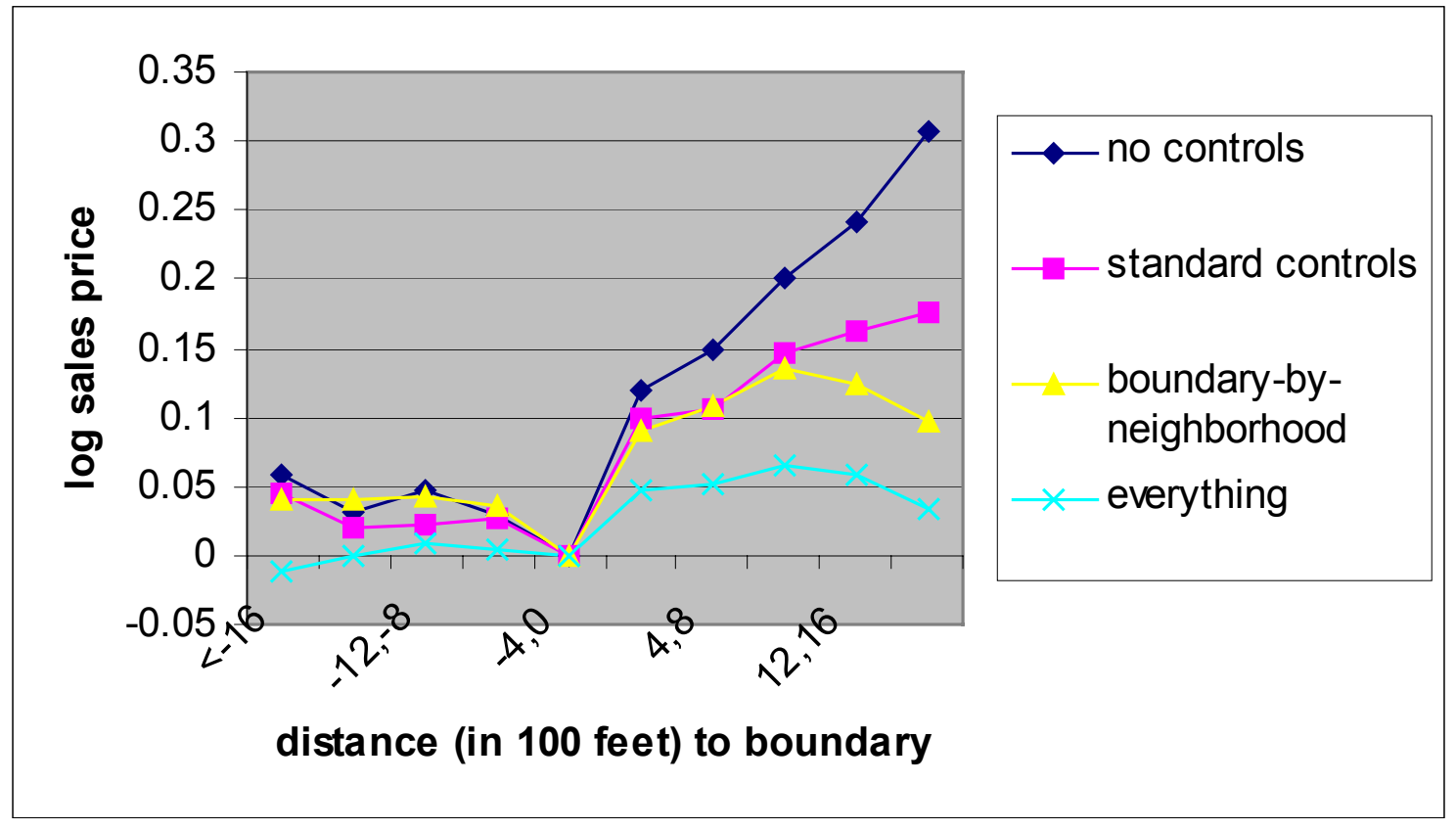


Figure 9. Percent black in census tracts assigned to a high school for parcels that had an increase of more than 5 percent (1), a decrease of more than 5 percent (-1), or less than a 5 percent change (0) resulting from redistricting in 1997.

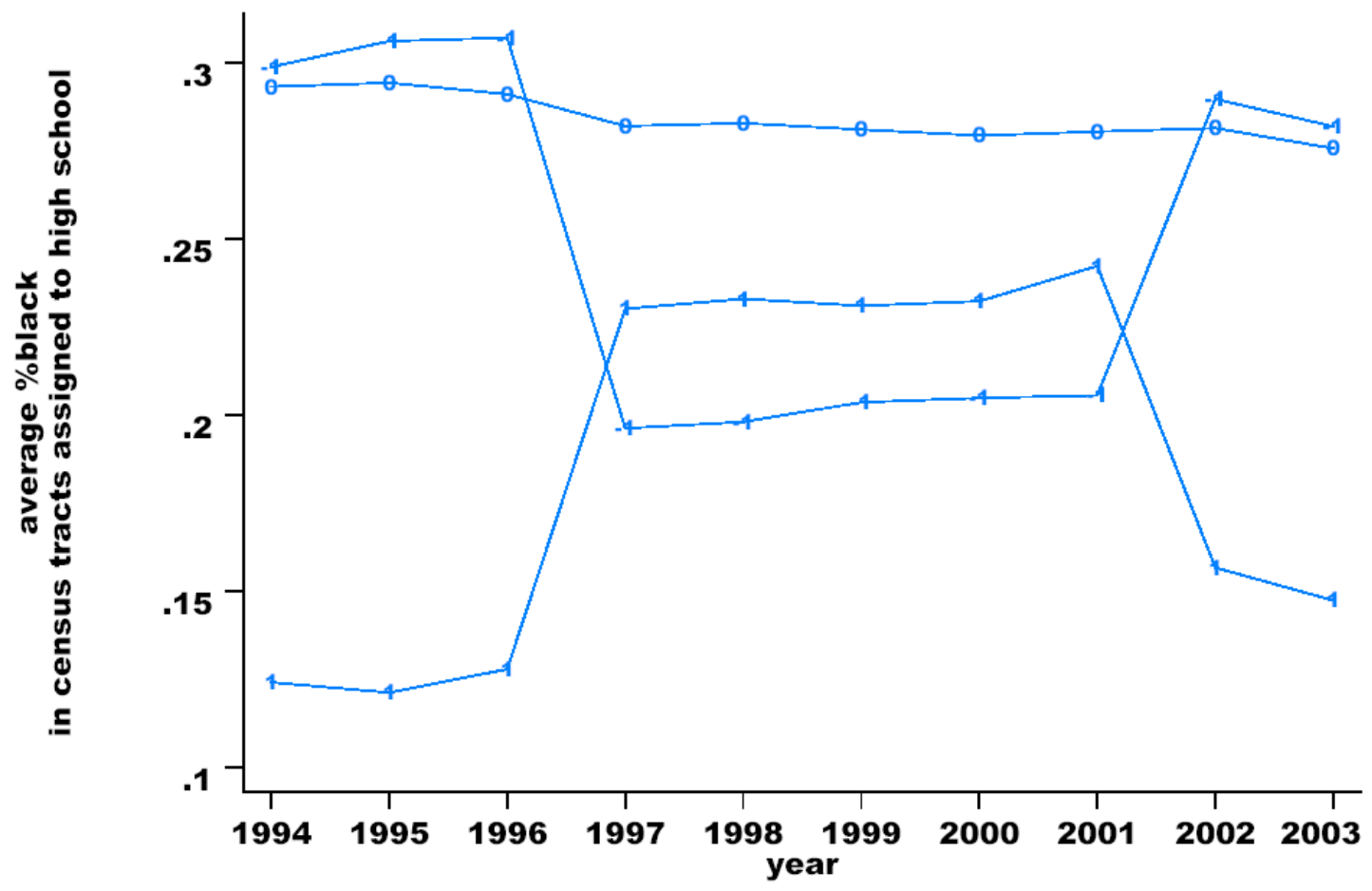


Figure 10. Average residual in log sales price for parcels assigned to a high school that had an increase in percent black of more than 5 percent (1), a decrease of more than 5 percent $(-1)$, or less than a 5 percent change (0) resulting from redistricting in 1997.

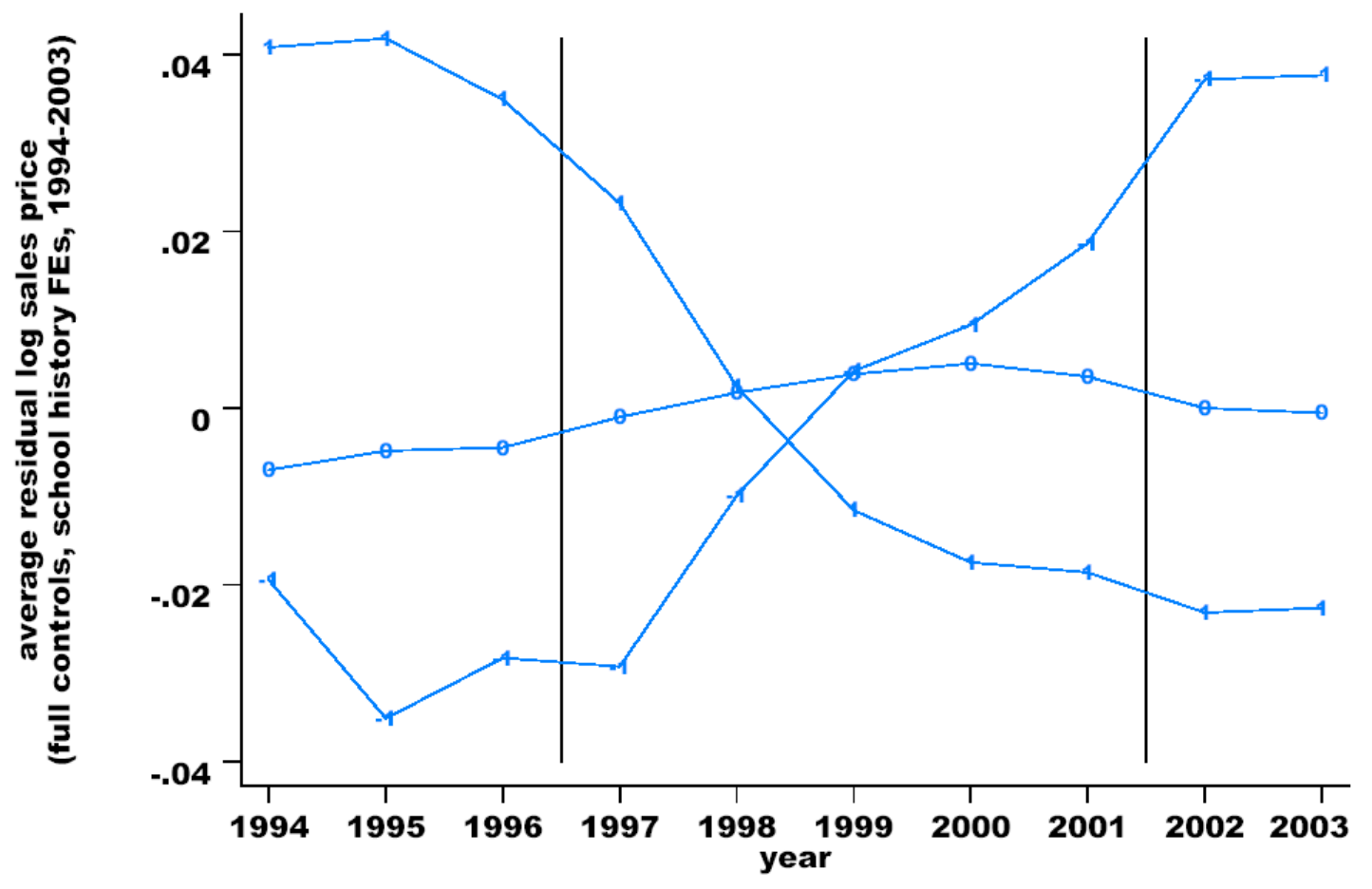




\section{Table 1. Sensitivity of Regression Discontinuity Estimates to Neighborhood and Housing Characteristic Controls}

Dependent Variable:Ln(Sales Price)

\begin{tabular}{|c|c|c|c|c|c|}
\hline & (1) & $(2)$ & (3) & (4) & (5) \\
\hline $\begin{array}{l}\text { Elem Math \& Read Score 1993-99 } \\
\text { (in student-level s.d. units) }\end{array}$ & $\begin{array}{c}0.527 \\
(0.073)\end{array}$ & $\begin{array}{c}0.311 \\
(0.050)\end{array}$ & $\begin{array}{c}0.138 \\
(0.046)\end{array}$ & $\begin{array}{c}0.098 \\
(0.040)\end{array}$ & $\begin{array}{c}0.128 \\
(0.038)\end{array}$ \\
\hline Distance to Elem School (miles) & $\begin{array}{l}-0.042 \\
(0.011)\end{array}$ & $\begin{array}{l}-0.032 \\
(0.009)\end{array}$ & $\begin{array}{l}-0.009 \\
(0.007)\end{array}$ & $\begin{array}{l}-0.005 \\
(0.008)\end{array}$ & $\begin{array}{l}-0.009 \\
(0.005)\end{array}$ \\
\hline \multicolumn{6}{|l|}{ Other Covariates: } \\
\hline $\begin{array}{l}\text { Base Covariates } \\
\text { Boundary Fixed Effects }\end{array}$ & Yes & $\begin{array}{l}\text { Yes } \\
84\end{array}$ & Yes & Yes & Yes \\
\hline Boundary-by-Neigh'd Fixed Effects & & & 496 & 496 & \\
\hline 2500 Sq. Foot Area Fixed Effects & & & & & 556 \\
\hline $\begin{array}{l}\text { Block Group Characteristics and } \\
\text { Building Quality Dummies }\end{array}$ & & & & Yes & Yes \\
\hline R-Squared & 0.82 & 0.84 & 0.88 & 0.89 & 0.89 \\
\hline Observations & 23,084 & 23,084 & 23,084 & 23,084 & 23,084 \\
\hline
\end{tabular}

Note: The dependent variable is $\ln ($ sales price). Sample was limited to existing home sales, on parcels with stable school assignments from 1993 through 2001, which were within 2000 feet of a school boundary, and where minimum distance at boundary was less than 500 feet. Base covariates included academic year dummies, month dummies, dummies for municipality, dummies for middle school and high school, number of bedrooms, bathrooms and half-baths, acreage, heated square feet, age, age $^{2}$ and dummies for basement, garage and air conditioning. Columns (4) and (5) also include 36 building quality dummies and percent black and median household income in the census block group in 2000. Huber-White standard errors allow for clustering at the school level. 
Table 2. Similar Results using Other Measures

of Elementary School Characteristics

Dependent Variable:

Ln(Sales Price)

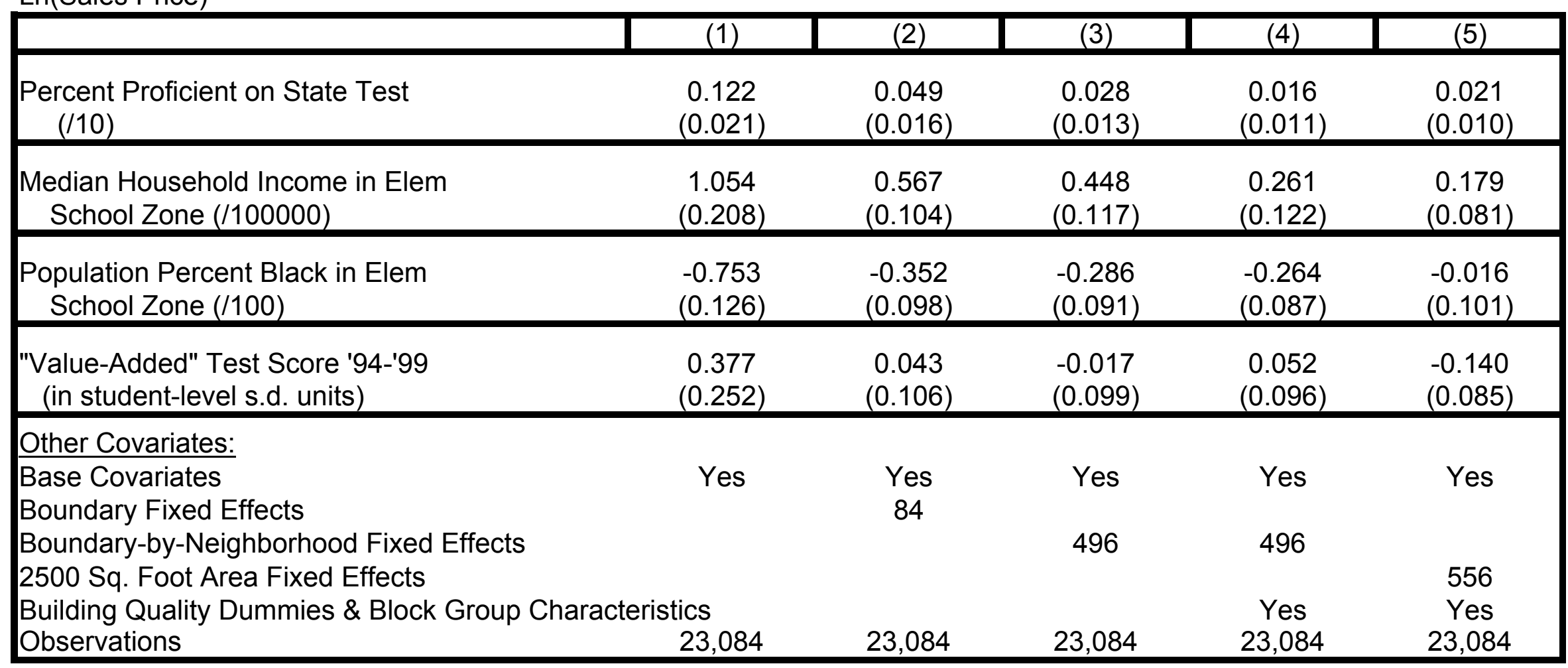

Note: Sample was limited to those parcels with stable school assignments from 1993 through 2001, which were within 2000 feet of a school boundary, and where minimum distance at boundary was less than 500 feet. Base covariates included academic year dummies, month dummies, dummies for municipality, dummies for middle school and high school, number of bedrooms, bathrooms and half-baths, acreage, heated square feet, age, age ${ }^{2}$ and dummies for basement, garage and air conditioning. Columns (4) and (5) also include 36 building quality dummies and percent black and median household income in the census block group in 2000. Huber-White standard errors allow for clustering at the school level. 
Table 3. Sensitivity of Regression Discontinuity Estimates to Choice of Subsample

\begin{tabular}{|c|c|c|c|c|c|}
\hline $\begin{array}{l}\text { Dependent Variable: } \\
\text { Ln(Sales Price) }\end{array}$ & $\begin{array}{l}<2000^{\prime} \\
\text { to Boundary }\end{array}$ & $\begin{array}{c}<1000 \\
\text { to Boundary }\end{array}$ & $\begin{array}{l}<500^{\prime} \\
\text { to Boundary }\end{array}$ & $\begin{array}{l}\text { Block Group } \\
<12 \% \text { Black }\end{array}$ & $\begin{array}{l}\text { Block Group } \\
>30 \% \text { Black }\end{array}$ \\
\hline & (1) & $(2)$ & $(3)$ & $(4)$ & $(5)$ \\
\hline $\begin{array}{l}\text { Elem Math \& Read Score 1993-99 } \\
\text { (in student-level s.d. units) }\end{array}$ & $\begin{array}{c}0.138 \\
(0.046)\end{array}$ & $\begin{array}{c}0.153 \\
(0.045)\end{array}$ & $\begin{array}{c}0.086 \\
(0.043)\end{array}$ & $\begin{array}{c}0.366 \\
(0.078)\end{array}$ & $\begin{array}{c}0.011 \\
(0.036)\end{array}$ \\
\hline Distance to Elem. School (miles) & $\begin{array}{l}-0.009 \\
(0.007)\end{array}$ & $\begin{array}{l}-0.008 \\
(0.005)\end{array}$ & $\begin{array}{l}-0.009 \\
(0.007)\end{array}$ & $\begin{array}{l}-0.010 \\
(0.012)\end{array}$ & $\begin{array}{c}0.007 \\
(0.006)\end{array}$ \\
\hline \multicolumn{6}{|l|}{ Other Covariates: } \\
\hline Base Covariates & Yes & Yes & Yes & Yes & Yes \\
\hline Boundary-by-Neigh'd Fixed Effects & Yes & Yes & Yes & Yes & Yes \\
\hline R-Squared & 0.88 & 0.89 & 0.87 & 0.85 & 0.72 \\
\hline Observations & 23,084 & 9,757 & 3,028 & 9,279 & 7,770 \\
\hline
\end{tabular}

Note: The dependent variable is $\ln$ (sales price). Sample was limited to existing home sales, on parcels with stable school assignments from 1993 through 2001, which were within 2000 feet of a school boundary, and where minimum distance at boundary was less than 500 feet. Base covariates included academic year dummies, month dummies, dummies for municipality, dummies for middle school and high school, number of bedrooms, bathrooms and half-baths, acreage, heated square feet, age, age $^{2}$ and dummies for basement, garage and air conditioning. Huber-White standard errors allow for clustering at the school level. 


\section{Table 4. Discontinuities in Housing Characteristics at Elementary School Boundaries}

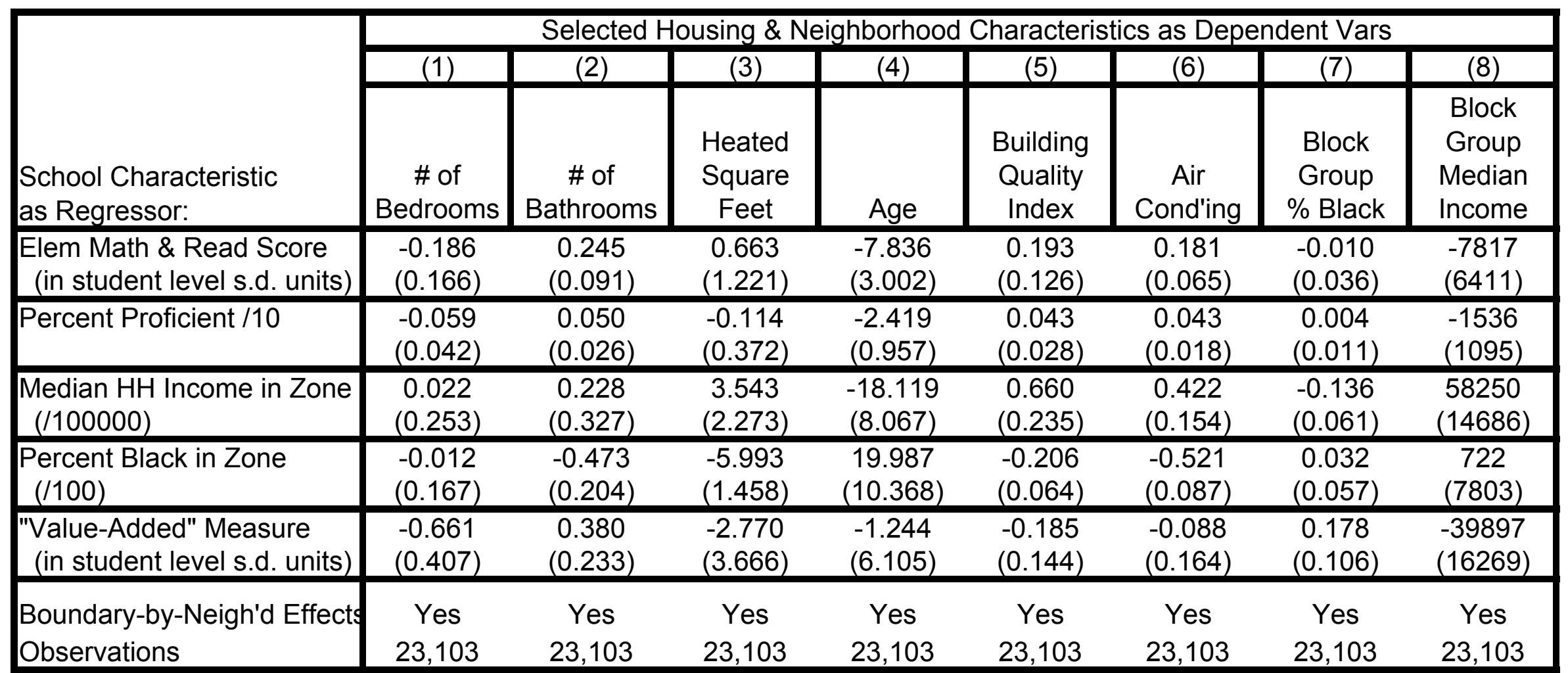

Note: Each cell reports the coefficients for separate regressions, using the housing characteristic in the column as the dependent variable and the school characteristic in the row as a regressor. Sample was limited to existing home sales, on parcels with stable school assignments from 1993 through 2001, which were within 2000 feet of a school boundary, and where minimum distance at boundary was less than 500 feet. Each regression also included academic year dummies, month dummies and dummies for municipality. The building quality index uses the coefficients from a regression of In(house price) on quality categories to constuct an index for each category. Huber-White standard errors allow for clustering at the school level. 


\section{Table 5. Housing Prices and Within-Neighborhood Changes in School Characteristics}

\begin{tabular}{|l|c|c|c|}
\hline & \multicolumn{3}{|c|}{ School Characteristic: } \\
\hline & $\begin{array}{c}\text { School } \\
\text { Zone } \\
\text { Percent } \\
\text { Black }\end{array}$ & $\begin{array}{c}\text { School } \\
\text { Zone } \\
\text { Median } \\
\text { Household } \\
\text { Income }\end{array}$ & $\begin{array}{c}\text { School } \\
\text { Percent } \\
\text { Proficient }\end{array}$ \\
\cline { 2 - 4 } & $(1)$ & $(2)$ & $(3)$ \\
\hline Ln(Sales price) & & & \\
\hline Level of School: & 0.034 & 0.045 & -0.237 \\
\hline Elementary school & $(0.066)$ & $(0.099)$ & $(0.140)$ \\
& -0.144 & 0.083 & -0.039 \\
Middle school & $(0.083)$ & $(0.091)$ & $(0.108)$ \\
& -0.419 & 0.284 & 0.184 \\
High school & $(0.074)$ & $(0.066)$ & $(0.063)$ \\
School Assignment History & Yes & Yes & Yes \\
Fixed Effects? & 89548 & 89548 & 87908 \\
Observations & 0.88 & 0.88 & 0.88 \\
\hline R-squared & & & \\
\hline
\end{tabular}

Note: The dependent variable is In(sales price). Sample included all existing home sales between 1994 and 2001. All specifications included base covariates (described in Table 1), 36 building quality dummies and percent black and median household income in the census block group. Also included were fixed effects for permutations of elementary, middle and high school assignments from 1993 through 2001. Huber-White standard errors allow for clustering at the permutation of school 


\section{Table 6. Housing Prices and Changes in School Zone Percent Black}

For Alternative Specifications of Fixed Effects

\begin{tabular}{|l|c|c|c|c|}
\hline & \multicolumn{3}{|c|}{ Type of Fixed Effect Included: } \\
\hline & $\begin{array}{c}\text { School } \\
\text { Assignment } \\
\text { History }\end{array}$ & $\begin{array}{c}\text { School } \\
\text { Assignment } \\
\text { History by } \\
\text { Neighborhood }\end{array}$ & $\begin{array}{c}\text { School } \\
\text { Assignment } \\
\text { History by } \\
\text { 2500' Block }\end{array}$ & Parcel \\
\cline { 2 - 5 } $\begin{array}{l}\text { Lependent Variable: } \\
\text { Ln(Sales price) }\end{array}$ & $(1)$ & $(2)$ & $(3)$ & $(4)$ \\
\hline Coefficient on & \multicolumn{4}{|c|}{} \\
School Zone \% Black: & 0.034 & 0.031 & 0.022 & 0.005 \\
Elementary school & $(0.066)$ & $(0.067)$ & $(0.065)$ & $(0.198)$ \\
Middle school & -0.144 & -0.165 & -0.176 & -0.261 \\
& $(0.083)$ & $(0.083)$ & $(0.080)$ & $(0.226)$ \\
High school & -0.419 & -0.414 & -0.406 & -0.651 \\
& $(0.074)$ & $(0.071)$ & $(0.072)$ & $(0.196)$ \\
Number of Fixed Effects: & 788 & 2023 & 3320 & 69247 \\
Observations & 89548 & 89548 & 89548 & 89647 \\
R-squared & 0.88 & 0.90 & 0.90 & 0.98 \\
\hline
\end{tabular}

Note: The dependent variable is In(sales price). Sample included all existing home sales between 1994 and 2001. Specifications 1-3 included base covariates (described in Table 1), 36 building quality dummies and percent black and median household income in the census block group. Specification 1 included fixed effects for permutations of elementary, middle and high school assignments from 1993 through 2001. Specification 2 included fixed effects for permutations of school assignments and neighborhood. Specification 3 included fixed effects for permutations of school assignment and 2500' square blocks. Specification 4 included parcel fixed effects, and only controlled for year and month dummies because the remaining household-level characteristics do not vary within parcel. Huber-White standard errors allow for clustering at the permutation of school assignments level. 


\section{Table 7. Effects of Changes in School Assignments (1994-2001)}

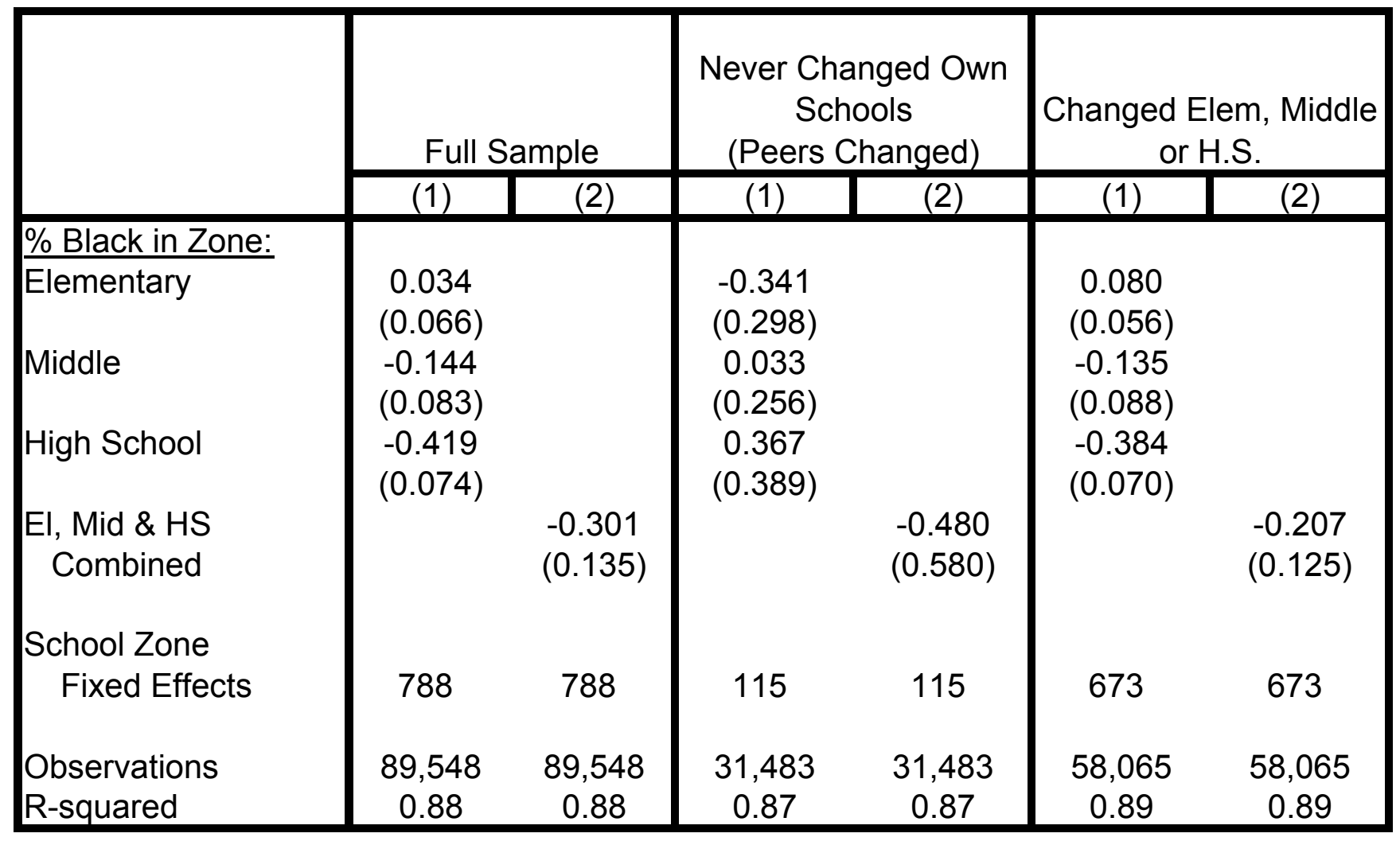

Note: The dependent variable is $\ln ($ sales price). See note in Table 5 for additional details 


\section{Table 8. Coefficients on Leads and Lagged Values of Percent Black in High School Zone}

\begin{tabular}{|c|c|c|c|c|c|}
\hline $\begin{array}{l}\text { Dependent Variable: } \\
\text { Ln(Sales Price) }\end{array}$ & (1) & (2) & (3) & (4) & (5) \\
\hline $\begin{array}{l}\text { Current Year } \\
\text { Year - } 1 \\
\text { Year - } 2 \\
\text { Year - } 3 \\
\text { Year + } 1 \\
\text { Year + } 2\end{array}$ & $\begin{array}{l}-0.425 \\
(0.077)\end{array}$ & $\begin{array}{c}-0.086 \\
(0.049) \\
-0.442 \\
(0.071)\end{array}$ & $\begin{array}{c}-0.091 \\
(0.049) \\
-0.219 \\
(0.053) \\
-0.287 \\
(0.057)\end{array}$ & $\begin{array}{l}-0.094 \\
(0.049) \\
-0.218 \\
(0.053) \\
-0.199 \\
(0.058) \\
-0.135 \\
(0.039)\end{array}$ & $\begin{array}{c}-0.113 \\
(0.045) \\
-0.217 \\
(0.053) \\
-0.196 \\
(0.059) \\
-0.123 \\
(0.043) \\
0.024 \\
(0.030) \\
0.009 \\
(0.040)\end{array}$ \\
\hline $\begin{array}{l}\text { Observations } \\
\text { R-squared }\end{array}$ & $\begin{array}{c}89,548 \\
0.88\end{array}$ & $\begin{array}{c}89,548 \\
0.88\end{array}$ & $\begin{array}{c}89,548 \\
0.88\end{array}$ & $\begin{array}{c}89,548 \\
0.88\end{array}$ & $\begin{array}{c}89,548 \\
0.88\end{array}$ \\
\hline
\end{tabular}

Note: The dependent variable is $\ln$ (sales price). See note in Table 5 for additional details. 


\section{Table 9. Identifying Effects of Changes in Percent Black in High School Zones and Neighborhoods}

\begin{tabular}{|c|c|c|c|c|c|}
\hline $\begin{array}{l}\text { Dependent Variable: } \\
\text { Ln(Sales Price) }\end{array}$ & (1) & (2) & (3) & (4) & (5) \\
\hline \multicolumn{6}{|l|}{ High School Zone: } \\
\hline Current Year & $\begin{array}{l}-0.094 \\
(0.049)\end{array}$ & $\begin{array}{l}-0.041 \\
(0.053)\end{array}$ & $\begin{array}{c}-0.02 \\
(0.046)\end{array}$ & $\begin{array}{c}0.043 \\
(0.170)\end{array}$ & $\begin{array}{c}0.056 \\
(0.152)\end{array}$ \\
\hline Year - 1 & $\begin{array}{l}-0.218 \\
(0.053)\end{array}$ & $\begin{array}{l}-0.197 \\
(0.071)\end{array}$ & $\begin{array}{l}-0.236 \\
(0.052)\end{array}$ & $\begin{array}{c}0.149 \\
(0.222)\end{array}$ & $\begin{array}{c}0.17 \\
(0.178)\end{array}$ \\
\hline Year - 2 & $\begin{array}{l}-0.199 \\
(0.058)\end{array}$ & $\begin{array}{l}-0.166 \\
(0.071)\end{array}$ & $\begin{array}{l}-0.186 \\
(0.056)\end{array}$ & $\begin{array}{l}-0.337 \\
(0.244)\end{array}$ & $\begin{array}{l}-0.283 \\
(0.190)\end{array}$ \\
\hline Year - 3 & $\begin{array}{l}-0.135 \\
(0.039)\end{array}$ & $\begin{array}{l}-0.045 \\
(0.042)\end{array}$ & $\begin{array}{l}-0.074 \\
(0.041)\end{array}$ & $\begin{array}{c}0.102 \\
(0.134)\end{array}$ & $\begin{array}{c}0.085 \\
(0.106)\end{array}$ \\
\hline \multicolumn{6}{|l|}{ Neighborhood: } \\
\hline$\overline{\text { Current Year }}$ & & & & $\begin{array}{l}-0.154 \\
(0.178)\end{array}$ & \\
\hline Year - 1 & & & & $\begin{array}{l}-0.429 \\
(0.238)\end{array}$ & \\
\hline Year - 2 & & & & $\begin{array}{c}0.154 \\
(0.241)\end{array}$ & \\
\hline \multirow{2}{*}{$\begin{array}{l}\text { Year - } 3 \\
\text { Fixed Effects: }\end{array}$} & & & & -0.254 & \\
\hline & & & & $(0.126)$ & \\
\hline \multirow{2}{*}{$\begin{array}{l}\text { School Zone } \\
\text { School Zone Trends } \\
\text { Neighborhood } \\
\text { Neighborhood X Year }\end{array}$} & Yes & Yes & & & \\
\hline & & Yes & Yes & Yes & $\begin{array}{l}\text { Yes } \\
\text { Yes }\end{array}$ \\
\hline Observations & 89,548 & 89,548 & 89,548 & 89,591 & 89,548 \\
\hline R-squared & 0.88 & 0.89 & 0.89 & 0.89 & 0.90 \\
\hline
\end{tabular}

Note: The dependent variable is $\ln ($ sales price). See note in Table 5 for additional details. 


\section{Table 10. Identifying Effects of School Assignments on Population Characteristics}

Dependent Variable: 2000-1990 Change in Block Group \% Black

\begin{tabular}{|c|c|c|c|c|c|}
\hline & (1) & (2) & (3) & (4) & (5) \\
\hline $\begin{array}{l}\text { \%Black in Elem Zone: } \\
\text { Change 2000-1991 } \\
\text { Baseline } 1991 \\
\text { \%Black in M.S. Zone: } \\
\text { Change } 2000-1991 \\
\text { Baseline } 1991 \\
\text { \%Black in H.S. Zone: } \\
\text { Change } 2000-1991 \\
\text { Baseline } 1991 \\
\text { \%Black E,M,HS Comb } \\
\text { Change } 2000-1991 \\
\text { Baseline } 1991 \\
\text { Diff from } 91 \text { Zone Mean: } \\
\text { Block group-Elem Zone } \\
\text { Block group-MS Zone } \\
\text { Block group-HS Zone } \\
\text { Block group-E,M,HS Comb }\end{array}$ & $\begin{array}{c}0.272 \\
(0.076) \\
0.302 \\
(0.050)\end{array}$ & $\begin{array}{c}0.286 \\
(0.166) \\
0.396 \\
(0.075)\end{array}$ & $\begin{array}{c}0.300 \\
(0.106) \\
0.582 \\
(0.113)\end{array}$ & $\begin{array}{c}0.147 \\
(0.082) \\
0.133 \\
(0.081) \\
\\
0.054 \\
(0.107) \\
0.017 \\
(0.160) \\
\\
0.216 \\
(0.130) \\
0.420 \\
(0.151)\end{array}$ & $\begin{array}{c} \\
0.392 \\
(0.153) \\
0.463 \\
(0.063)\end{array}$ \\
\hline $\begin{array}{l}\text { Observations } \\
\text { R-squared }\end{array}$ & $\begin{array}{c}224463 \\
0.11\end{array}$ & $\begin{array}{c}224463 \\
0.11\end{array}$ & $\begin{array}{c}224463 \\
0.14\end{array}$ & $\begin{array}{c}224463 \\
0.15\end{array}$ & $\begin{array}{c}224463 \\
0.14\end{array}$ \\
\hline
\end{tabular}

Note: The dependent variable is the change in percent African American in the census block gorup between 1990 and 2000. Sample consists of all residential housing parcels. Also included were fixed effects for permutations of elementary, middle and high school assignments from 1993 through 2001. Huber-White standard errors allow for clustering at the permutation of school assignments level. 


\section{Table 10. Identifying Effects of School Assignments on Population Characteristics (Continued)}

Dependent Variable: 2000-1990 Change in Block Group \% Black

\begin{tabular}{|c|c|c|c|c|c|}
\hline & (1) & (2) & (3) & (4) & (5) \\
\hline \%Black in Elem Zone: & & & & & \\
\hline Change 2000-1991 & $\begin{array}{c}0.233 \\
(0.051)\end{array}$ & & & $\begin{array}{c}0.205 \\
(0.054)\end{array}$ & \\
\hline Baseline 1991 & $\begin{array}{c}0.221 \\
(0.031)\end{array}$ & & & $\begin{array}{c}0.405 \\
(0.062)\end{array}$ & \\
\hline \%Black in M.S. Zone: & & & & & \\
\hline Change 2000-1991 & & $\begin{array}{c}0.407 \\
(0.151)\end{array}$ & & $\begin{array}{c}0.003 \\
(0.074)\end{array}$ & \\
\hline Baseline 1991 & & $\begin{array}{c}0.345 \\
(0.067)\end{array}$ & & $\begin{array}{l}-0.159 \\
(0.103)\end{array}$ & \\
\hline \%Black in H.S. Zone: & & & & & \\
\hline Change 2000-1991 & & & $\begin{array}{l}0.295 \\
(0.070)\end{array}$ & $\begin{array}{c}0.003 \\
(0.086)\end{array}$ & \\
\hline Baseline 1991 & & & $\begin{array}{c}0.499 \\
(0.089)\end{array}$ & $\begin{array}{c}0.049 \\
(0.099)\end{array}$ & \\
\hline$\%$ Black E,M,HS Comb & & & & & \\
\hline Change 2000-1991 & & & & & $\begin{array}{c}0.182 \\
(0.120)\end{array}$ \\
\hline Baseline 1991 & & & & & $\begin{array}{l}0.448 \\
(0.048)\end{array}$ \\
\hline Diff from ' 91 Zone Mean: & & & & & \\
\hline Block group-Elem Zone & $\begin{array}{l}-0.395 \\
(0.039)\end{array}$ & & & & \\
\hline Block group-MS Zone & & $\begin{array}{l}-0.237 \\
(0.034)\end{array}$ & & & \\
\hline Block group-HS Zone & & & $\begin{array}{l}-0.209 \\
(0.040)\end{array}$ & & \\
\hline Block group-E,M,HS Comb & & & & $\begin{array}{l}-0.389 \\
(0.041)\end{array}$ & $\begin{array}{l}-0.345 \\
(0.034)\end{array}$ \\
\hline $\begin{array}{l}\text { Observations } \\
\text { R-squared }\end{array}$ & $\begin{array}{c}224463 \\
0.47\end{array}$ & $\begin{array}{c}224463 \\
0.31\end{array}$ & $\begin{array}{c}224463 \\
0.30\end{array}$ & $\begin{array}{c}224463 \\
0.48\end{array}$ & $\begin{array}{c}224463 \\
0.45\end{array}$ \\
\hline
\end{tabular}

Note: The dependent variable is the change in percent African American in the census block gorup between 1990 and 2000. Sample consists of all residential housing parcels. Also included were fixed effects for permutations of elementary, middle and high school assignments from 1993 through 2001. Huber-White standard errors allow for clustering at the permutation of school assignments level. 